\title{
The Philadelphia chromosome in leukemogenesis
}

\author{
Zhi-Jie Kang 1,2, Yu-Fei Liu ${ }^{1,2}$, Ling-Zhi Xu ${ }^{3}$, Zi-Jie Long ${ }^{4}$, Dan Huang ${ }^{1}$, Ya Yang ${ }^{1,2}$, Bing Liu ${ }^{1,2}$, Jiu-Xing Feng ${ }^{1,2}$, \\ Yu-Jia Pan ${ }^{1,2}$, Jin-Song Yan ${ }^{1 *}$ and Quentin Liu ${ }^{1,2^{*}}$
}

\begin{abstract}
The truncated chromosome 22 that results from the reciprocal translocation $t(9 ; 22)(q 34 ; q 11)$ is known as the Philadelphia chromosome (Ph) and is a hallmark of chronic myeloid leukemia (CML). In leukemia cells, Ph not only impairs the physiological signaling pathways but also disrupts genomic stability. This aberrant fusion gene encodes the breakpoint cluster region-proto-oncogene tyrosine-protein kinase (BCR-ABL1) oncogenic protein with persistently enhanced tyrosine kinase activity. The kinase activity is responsible for maintaining proliferation, inhibiting differentiation, and conferring resistance to cell death. During the progression of CML from the chronic phase to the accelerated phase and then to the blast phase, the expression patterns of different BCR-ABL1 transcripts vary. Each BCR-ABL1 transcript is present in a distinct leukemia phenotype, which predicts both response to therapy and clinical outcome. Besides CML, the Ph is found in acute lymphoblastic leukemia, acute myeloid leukemia, and mixed-phenotype acute leukemia. Here, we provide an overview of the clinical presentation and cellular biology of different phenotypes of Phpositive leukemia and highlight key findings regarding leukemogenesis.
\end{abstract}

Keywords: Chronic myeloid leukemia, BCR-ABL1, Philadelphia chromosome, Translocations, Signaling pathway

\section{Background}

Leukemia has among the highest mortalities of any cancer [1]. Chronic myeloid leukemia (CML) accounts for 15\%$20 \%$ of all adult leukemias [2]. The Philadelphia chromosome $(\mathrm{Ph})$ is the truncated chromosome 22 generated by the reciprocal translocation $\mathrm{t}(9 ; 22)(\mathrm{q} 34 ; \mathrm{q} 11)$ and was first identified in 1960 in a patient with CML [3]. Translocation of the proto-oncogene tyrosine-protein kinase $(A B L 1)$ gene located on chromosome 9 to the breakpoint cluster region $(B C R)$ gene located on chromosome 22 results in a $B C R-A B L 1$ fusion gene on the Ph $[4,5]$. Three $B C R-A B L 1$ fusion gene hybrids encode BCR-ABL1 protein isoforms p210, p190, and p230, which have persistently enhanced tyrosine kinase (TK) activity. These aberrantly activated kinases disturb downstream signaling pathways, causing

\footnotetext{
*Correspondence: yanjsdmu@126.com; liuq9@mail.sysu.edu.cn

${ }^{1}$ Department of Hematology, The Second Affiliated Hospital, Institute of Cancer Stem Cell, Dalian Medical University, Dalian 116023, Liaoning, P. R. China

${ }^{2}$ State Key Laboratory of Oncology in South China, Sun Yat-sen University Cancer Center, Guangzhou 510060, Guangdong, P. R. China

Full list of author information is available at the end of the article
}

enhanced proliferation, differentiation arrest, and resistance to cell death $[6,7]$. Tyrosine kinase inhibitors (TKIs) targeting the BCR-ABL1 protein are the most successful targeted therapy for Ph-positive leukemia. However, therapeutic resistance and disease progression are the current barriers to improve the prognosis of patients with $\mathrm{Ph}$ positive leukemia [8-10]. Leukemia stem cells and BCR$\mathrm{ABL}$ kinase domain mutations may be the keys to solve these problems [11]. The $\mathrm{Ph}$ is not limited to CML; it is also detected in cases of acute myeloid leukemia (AML) $[12,13]$, acute lymphoblastic leukemia (ALL; almost all of which are B-cell ALL, rarely T-cell ALL) [14], and mixedphenotype acute leukemia (MPAL) [15-17]. The presence of the $\mathrm{Ph}$ results in patients with different leukemia phenotypes having substantially different prognoses. In addition, other concurrent genomic abnormalities are more common in leukemia cells with $\mathrm{Ph}$ than in those without. These genomic variations, in combination with BCRABL1 transcripts, play an important role during leukemogenesis [18-20].

However, the extent of the occurrence of the $\mathrm{Ph}$ and the types of $B C R-A B L 1$ transcripts found in different 
leukemia phenotypes, the exact role of the translocation in leukemogenesis, and the culprit of therapeutic resistance are still not fully elucidated. Here, we review the current understanding of this topic.

\section{The Ph, BCR-ABL1 fusion gene, and BCR-ABL hybrid protein}

Molecular investigation into the $\mathrm{Ph}$ observed in $\mathrm{CML}$ revealed a consistent genomic recombination between two genes $-B C R$ on the long arm of chromosome 22 and $A B L 1$ on the long arm of chromosome 9-resulting in their juxtaposition, which generates the $B C R$ $A B L 1$ fusion gene [21]. The location of the $B C R$ and $A B L 1$ genomic breakpoints is highly variable [22], but the recombination usually involves fusion of intron 1 , intron $13 / 14$, or exon 19 of $B C R$ with a 140 -kb region of $A B L 1$ between exons $1 \mathrm{~b}$ and 2 (Fig. 1a). Referred to as p $210^{\mathrm{BCR}-\mathrm{ABL} 1}$, the fusion of $B C R$ exon 13 and $A B L 1$ exon 2 (e13a2) or e14a2 constitutes the major BCR-ABL1 transcript (M-BCR, originally referred to as b2a2 and b3a2). Both transcripts result in a hybrid $210-\mathrm{kDa}$ protein. p210 ${ }^{\text {BCR-ABL1 }}$ is most commonly detected in CML and occasionally in ALL or AML. p190 ${ }^{\text {BCR-ABL1 }}$ (e1a2) constitutes the minor $B C R-A B L 1$ transcript (m-BCR), which encodes a hybrid $190-\mathrm{kDa}$ protein. $\mathrm{p} 190^{\mathrm{BCR}-\mathrm{ABL}}$ is commonly detected in B-cell ALL (B-ALL) and occasionally in AML but is rarely observed in CML [7]. p230 ${ }^{\text {BCR-ABL1 }}$ (e19a2), also known as the $\mu B C R-A B L 1$ transcript ( $\mu$-BCR), encodes a hybrid $230-\mathrm{kDa}$ protein. $\mathrm{p} 230^{\mathrm{BCR}-\mathrm{ABL} 1}$ is generated by the fusion of almost the entire $B C R$ gene with the $A B L 1$ gene and is considered a molecular diagnostic marker for neutrophilic-chronic myeloid leukemia (CML-N) [23].

The BCR-ABL1 protein in CML contains several domains from both BCR and ABL1. The domains from $\mathrm{BCR}$ include an $\mathrm{N}$-terminal coiled-coil domain $(\mathrm{CC}$; amino acids 1-63), a Ser/Thr kinase domain containing a docking site (phosphorylated tyrosine 177, Y177) for the adaptor protein growth factor receptor-bound protein 2 (GRB2) [24, 25], and a ras homolog gene family/Guanine nucleotide exchange factors (Rho/GEF) kinase domain (amino acids 298-413) [26], whereas the domains from

a

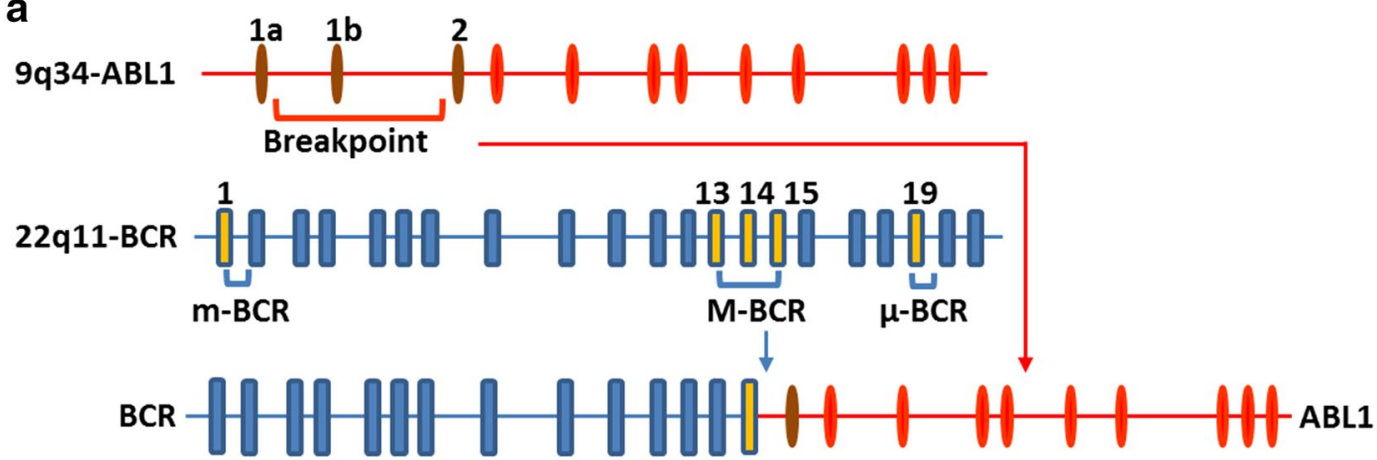

b

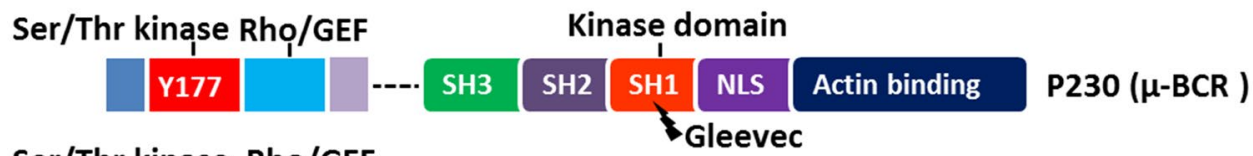

Ser/Thr kinase Rho/GEF

\begin{tabular}{|c|c|c|c|c|c|c|}
\hline Y177 & - & SH3 & SH2 & SH1 NLS Actin binding & P210 (M-BCR )
\end{tabular}

Ser/Thr kinase

Y177

\begin{tabular}{ll|l|l} 
SH3 & SH2 & SH1 & NLS \\
Actin binding
\end{tabular}

P190 (m-BCR )

Fig. 1 The structure of the breakpoint cluster region $(B C R)$-proto-oncogene tyrosine-protein kinase ( $A B L 1$ ) gene and protein. a The $B C R-A B L 1$ fusion gene consists of the $5^{\prime}$ end of the $B C R$ gene located at $22 q 11$ and the $3^{\prime}$ end of the $A B L 1$ gene located at $9 q 34$. The breakpoints of the translocation usually involve the intron 13 or 14 of $B C R$, named major breakpoint (M-BCR), intron 1 of $B C R$, named minor breakpoint (m-BCR), and exon 19 of $B C R$, named $\mu$ breakpoint $(\mu-B C R$ ). For $A B L 1$, the breakpoint always involves the region between exons $1 \mathrm{~b}$ and 2 . $\mathbf{b}$ The $B C R-A B L 1$ protein contains the Ser/Thr kinase domain and the Rho/GEF domain of BCR and the src homology (SH) domains, nuclear localization signal (NLS), and actin-binding domains from ABL1. The SH1 kinase domain is the target of imatinib. The different breakpoints that generate the p230, p210, and p190 isoforms are shown 
ABL1 include src homology (SH) domains ( $\mathrm{SH} 1 / \mathrm{SH} 2)$, a proline-rich domain, and DNA- and actin-binding domains. Although different transcripts encode different proteins, a common feature of all the hybrid proteins (p210/190/230) is the constitutively active protein kinase activity compared to wild-type $A B L 1$ (Fig. 1b).

The N-terminal CC domain and Y177 of BCR are essential for the activation of ABL1 kinase [27, 28]. Targeting the $\mathrm{CC}$ domain to disrupt the tetramerization of BCRABL1 reduces its kinase activity and increases sensitivity to the TKI imatinib mesylate (imatinib, also known by the trade names Gleevec or Glivec) [29,30], thus indicating that inhibition of tetramerization can contribute to overcoming imatinib resistance. In CML, Y177 plays a critical role in leukemic cell progenitor expansion, proliferation, and survival. Mutation of the GRB2-binding site at Y177 in p210 ${ }^{\mathrm{BCR}-\mathrm{ABL} 1}$ fails to induce a CML-like disease [24] and enhances sensitivity to imatinib by inhibiting RAS and protein kinase $\mathrm{B}$ (PKB, also named $\mathrm{AKT}$ ) activation in CML [31]. These results show that Y177 is essential for transformation of CML by BCR-ABL1, and that it has potential as a target for overcoming imatinib resistance. The Rho/GEF protein plays a major role in activating differentiation in BCR-ABL1-induced leukemogenesis [32]. Inhibition of Rho kinase suppresses DNA synthesis in BCR-ABL1-transfected cells and also inhibits the proliferation and survival of CML progenitor cells [33, 34].

ABL1 protein, one of the non-receptor TKs, is present throughout hematopoietic development, with declining levels during myeloid maturation. The autophosphorylation site in the activation loop of its SH1 domain constitutes a switch between the inactive and active kinase conformation as it conjugates adenosine triphosphate (ATP) [35]. Imatinib and other kinase inhibitors compete with ATP to bind the autophosphorylation site, blocking the downstream signaling pathway [36]. In the "closed" conformation, the SH2 domain inhibits ABL1 activity, whereas in the "open" conformation, it promotes ABL1 activation through binding to the C-terminal of the SH1 domain [37]. Importantly, docking of the $\mathrm{SH} 2$ domain to the C-lobe of the kinase is controlled by the myristate moiety at the $\mathrm{N}$-terminal of the $\mathrm{SH} 3$ domain. $\mathrm{N}$-terminal myristoyl modification of the SH3 domain of ABL1 binds to the SH1 domain (the kinase domain) and induces conformational changes that allow the $\mathrm{SH} 2$ and SH3 domains to dock onto it [38, 39]. Mutant SH3 domain of ABL1 (exon 1b) with a blocked myristatebinding site shows strongly deregulated TK activity [38]. Also, blocking the myristate-binding site completely abolished leukemogenesis in mice and increased the sensitivity of imatinib-resistant BCR-ABL1-bearing mutants to TKI inhibition [40, 41]. These findings suggest that the myristate-binding site of the $\mathrm{SH} 3$ domain of ABL1 is a potential novel allosteric target for pharmacologic intervention.

\section{Ph in different phenotypes of leukemia $\mathrm{Cml}$}

The BCR-ABL1 fusion gene is a hallmark of CML. Three discrete clinical stages are defined for CML: the chronic phase (CML-CP), the accelerated phase (CML-AP), and the blast crisis (CML-BC). Without therapeutic intervention, the disease follows a natural progression from relatively benign CML-CP, through CML-AP, to terminal CML-BC. The phenotype of CML-BC can be myeloid or lymphoid or, in rare cases, both. Myeloid $\mathrm{BC}$ is more commonly observed than lymphoid BC. In lymphoid BC, the predominant lineage is $\mathrm{B}$-cell, representing about $30 \%$ of cases [42].

Most CML patients have M-BCR transcripts with b14a2 (55\%) or b13a2 (40\%) junctions (p210 ${ }^{\text {BCR-ABL1 }}$ ). In $5 \%$ of CML cases, both b13a2 and b14a2 transcripts are detected $[43,44]$. However, the e1a2 (p190 ${ }^{\text {BCR-ABL1})}$ transcript is frequently present at a low level in patients with p210 $10^{\text {BCR-ABL1 }}$-positive leukemia [45]. Approximately $52 \%$ of Ph-positive CML cases co-express p210 $10^{\text {BCR-ABL1 }}$ and $\mathrm{p} 190^{\mathrm{BCR}-\mathrm{ABL} 1}$ transcripts, with the other $48 \%$ exclusively expressing $\mathrm{p} 210^{\mathrm{BCR}-\mathrm{ABL} 1}$ [44]. All CML-BC patients co-express both transcripts [44]. Further details were provided in a study of 250 Mexican Ph-positive CML patients, which found that $90.4 \%$ of patients expressed p210 $10^{\mathrm{BCR}-\mathrm{ABL} 1}$, and approximately $7 \%$ of patients with p210 ${ }^{\text {BCR-ABL1 }}$ expressed both isoforms (b3a2/b2a2); however, co-expression of p190/p210 ${ }^{\text {BCR-ABL1 }}$ was seen in only $5 \%$ of patients [46]. Nevertheless, the prognosis for CML patients who co-express two or all p190/210/230 BCR-ABL1 transcripts is poor [46]. Consistently, CML patients who co-express p210/p190 ${ }^{\text {BCR-ABL1 }}$ have considerably higher white blood cell (WBC) and blast cell counts at any time of testing, including diagnosis, than patients who express only p $210^{\text {BCR-ABL1 }}$ [44].

The position of the BCR breakpoint is also associated with prognosis. M-BCR rearrangement is predictive of response to therapy [47], whereas the presence of a double $\mathrm{Ph}$ indicates a poor prognosis [42]. However, no significant survival difference was found between patients with b13a2 and those with b14a2 mRNA junctions [48].

\section{Acute lymphoblastic leukemia}

$B C R-A B L 1$ is not restricted to CML. It is also present in $11 \%-29 \%$ of ALL patients [49] but is relatively rare in childhood ALL (1\%-3\%) [50]. BCR-ABL1 presence in ALL patients increases with age [51] and has been reported to be as high as $50 \%$ in patients 60 years of age or older [52]. With few exceptions, Ph-positive ALL 
patients are diagnosed with B-ALL [53-55], and most cases of Ph-positive ALL express the p190 ${ }^{\text {BCR-ABL1 }}$ transcript. The $\mathrm{p} 210^{\mathrm{BCR}-\mathrm{ABL1}}$ transcript is detected in $30 \%$ of adult and $20 \%$ of childhood patients with Ph-positive ALL [43, 45, 56-58]. The BCR-ABL1 variant e3a2 (exon 3 of BCR and exon 2 of ABL1) can also be detected in cases of Ph-positive ALL, which is similar to ALL with p190 ${ }^{\text {BCR-ABL1 }}$ transcript [59].

Prognosis of both adults and children with Ph-positive ALL treated with standard chemotherapy is very poor, with less than $5 \%$ of adults being cured $[55,60]$. Fortunately, the combination of chemotherapy with the TKI imatinib has remarkable efficacy on newly diagnosed $\mathrm{Ph}$ positive ALL, achieving a complete remission rate of $95 \%$ and a patient survival rate of $55 \%$ at 3 years [61].

\section{Acute myeloid leukemia}

$B C R-A B L 1$ transcripts are rarely found in AML. Less than $1.5 \%$ of AML patients harbor the $B C R-A B L 1$ fusion gene [62-64]. Ph-positive AML is cytogenetically indistinguishable from Ph-positive CML, but molecular studies show that, in $50 \%$ of cases, the breakpoint on chromosome 22 in Ph-positive AML is different from those very consistently found in CML [65]. Furthermore, studies have confirmed that $B C R-A B L 1$-positive AML is a unique acute leukemia with some features distinct from myeloid CML-BC. These features include less marked splenomegaly, fewer peripheral basophiles, and a lower myeloid/erythroid ratio, and bone marrow cellularity [64] compared with myeloid CML-BC. In addition, the loss within the immunoglobulin genes (deletion of 14q32) in some cases of de novo $\mathrm{Ph}$-positive AML can distinguish it from myeloid CML-BC [66]. However, the median survivals of Ph-positive AML and myeloid CML-BC patients are similar (9 vs. 7 months, $P=0.54$ ) [64].

\section{Mixed-phenotype acute leukemia}

The $\mathrm{Ph}$ is one of the most frequent aberrant cytogenetic findings in MPAL. The World Health Organization (WHO) defines MPAL as acute leukemia with a mixed phenotype containing two morphologically and immunophenotypically distinct populations of blasts or showing a single blast cell population expressing mixed phenotypic markers [67]. Many of these cases have a dimorphic population of blasts, with the majority being of B-lymphoid/myeloid lineage (59\%-60\%), followed by T-lymphoid/myeloid (32\%-35\%), T-/B-lymphoid (4\%), and trilineage $(2 \%-4 \%)[16,68]$. Ph-positive MPAL is defined as acute leukemia meeting the criteria for MPAL in which the blasts also have a detectable $\mathrm{Ph}$ or $B C R$ $A B L 1$ fusion transcript. The frequency of Ph-positive MPAL is $17 \%-35 \%$ in adult MPAL patients, whereas studies of pediatric patients report a much lower rate of
$3 \%[69,70]$. No obvious difference was found between the $B C R-A B L 1$ transcript types expressed in adult cases $[71,72]$, but $30 \%$ of cases have additional chromosomal aberrations [72]. Importantly, compared with other phenotypes of leukemia, Ph-positive MPAL has a much worse outcome [16, 68]. Studies of Ph-positive MPAL are rare, and there is no consensus on the most appropriate therapy for this subtype. Although TKIs have improved the prognosis of Ph-positive MPAL, adult patients are still considered for hematopoietic stem cell (HSC) transplantation during the first remission.

\section{What role does $\mathrm{Ph}$ play in leukemogenesis?}

The BCR-ABL1 fusion protein was first indicated as the crucial driver of CML in mouse studies, which showed that expression of $\mathrm{p} 210^{\mathrm{BCR}-\mathrm{ABL} 1}$ in the bone marrow caused a CML-like disease. The progression of p210 ${ }^{\mathrm{BCR}-\mathrm{ABL} 1}$-associated disease in transgenic mice is consistent with the apparent indolence of human CMLCP $[73,74]$. Expression of p $190^{\text {BCR-ABL1 }}$ at a level similar to that in the $\mathrm{p} 210^{\mathrm{BCR}-\mathrm{ABL} 1}$-transgenic model results in a clinically distinct condition. Voncken et al. [75] demonstrated the development of de novo B-cell leukemia in mice exclusively transgenic for $\mathrm{p} 190^{\mathrm{BCR}-\mathrm{ABL} 1}$, with a relatively short period of latency. Furthermore, Castellanos et al. [76] created an in-frame fusion of p190 $190^{\mathrm{BCR}-}$ ABL1 that mimics the human chromosomal translocation by homologous recombination in embryonic stem cells. The chimeric mice generated with the mutant embryonic stem cells systematically developed B-ALL, which was detected with elevated TK activity [77]. The TKI imatinib, the first agent targeting the TK activity of BCRABL1 protein, has become the first-line therapy for all patients with Ph-positive CML; it is also an indispensable therapy for Ph-positive ALL. Imatinib has changed the prognosis of CML radically over the last 15 years and improved the overall survival of ALL patients.

In addition to its TK activity, the SH2 domain of BCR$\mathrm{ABL} 1$ is also required for induction of CML-like disease in mice, but, interestingly, $\mathrm{SH} 2$ is not required for lymphoid leukemogenesis [78]. BCR-ABL1 with deleted SH2 or the R1057K mutant on $\mathrm{SH} 2$ of $\mathrm{p} 210^{\mathrm{BCR}-\mathrm{ABL} 1}$ retains the ability to induce a fatal myeloproliferative disorder (MPD) with an extended latency [79]. Consistently, in cells transfected with SH2-mutated BCR-ABL1 or BCRABL1, the B-lymphoid expansion was diminished, suggesting that the BCR-ABL1-induced MPD suppresses B-lymphoid expansion [79].

\section{Pathways associated with BCR-ABL1}

The transforming activity of BCR-ABL1 is due to its constitutive TK activity, which contributes to the maintenance of cell proliferation, inhibits differentiation, and 
promotes resistance to cell death. BCR-ABL1 kinase hyperactivity results in the activation of signaling pathways and deregulation of cellular processes [80]. Most of these pathways have been demonstrated in CML and ALL mouse models. The main pathways associated with BCR-ABL1 activity are presented in Fig. 2.

\section{The JAK2/STAT pathway}

Activation of Janus kinase (JAK)1-3 [81] and signal transducers and activators of transcription (STAT)1, 3, 5, and $6[81,82]$ has been confirmed experimentally in p190/

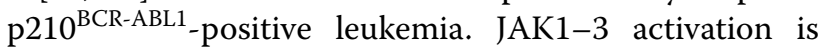
mediated by the interaction of BCR-ABL1 with cytokine receptors [83]. BCR-ABL1 kinase directly enhances JAK2/STAT activation to promote cell growth/survival in CML models $[84,85]$, and it requires an intact JAK2/ STAT5 pathway to enable oncogenic transformation [83]. JAK3 expression is limited to hematopoietic cells, and JAK3-knockout mice have developmental defects in lymphoid cells and expansion of the myeloid lineages [86-89]. JAK2 directly phosphorylates BCR-ABL1 at Y177 and increases BCR-ABL1 protein stability, thus enhancing BCR-ABL1 signaling $[24,90]$. Moreover, JAK2 induces mRNA expression of the oncogene $c-M Y C$ and protects c-MYC protein from degradation [91]. c-MYC overexpression plays a critical role in BCR-ABL1 transformation [92] and is a downstream target of activated JAK2 in BCR-ABL1-positive cells. Survivin is overexpressed in BCR-ABL1-positive cells [93], and BCR-ABL1 activates $\mathrm{C}-\mathrm{MYC}$ to induce transactivation of the survivin promoter via JAK2/phosphatidylinositol 3-kinase (PI3K) signaling pathways [94]. These findings indicate that JAK2 controls BCR-ABL1 stability and oncogenic signaling in BCR-ABL1-positive cells [95]. Both JAK2 inhibition and knockdown reduce levels of phosphorylated STAT5 (p-STAT5) and inhibit the RAS-PI3K pathway. By

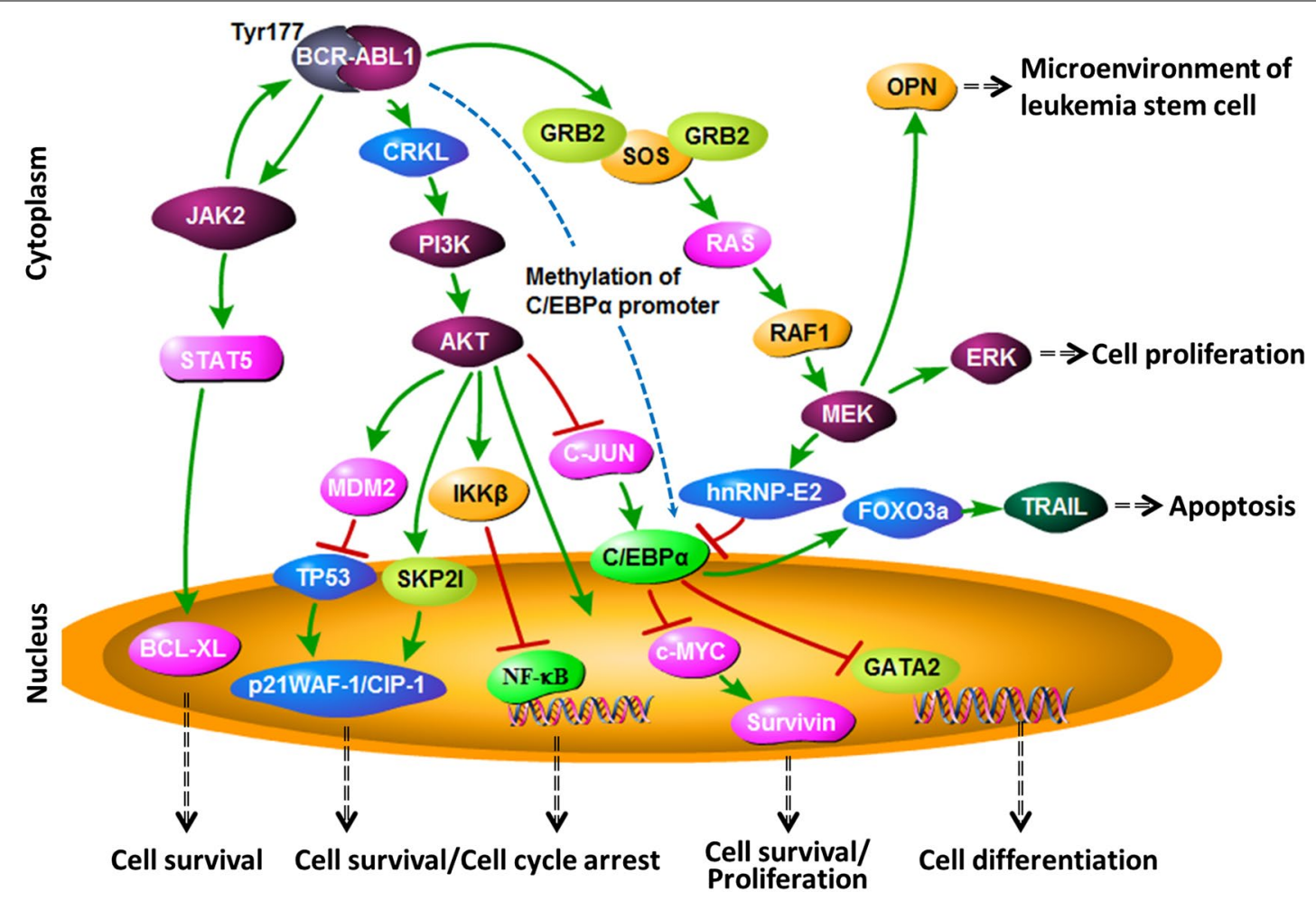

Fig. 2 Main pathways regulated by the BCR-ABL1 protein. The downstream pathways regulated by BCR-ABL1 protein associated with cell survival, cell proliferation, cell cycle, cell differentiation, apoptosis, and the microenvironment of leukemia stem cells. Dark violet shapes indicate the kinase; lavender pink shapes indicate the proven oncoprotein; blue shapes indicate the proven tumor suppressor protein; and other color shapes indicate the proteins existing in normal cells. Red solid lines indicate inhibiting; green solid lines indicate activating. Blue dotted lines indicate that the results need further confirmation. Black dotted lines indicate the functions associated with the signaling pathway. JAK2 janus kinase 2, STAT5 signal transducers and activators of transcription 5, BCR-XL B-cell lymphoma-extra-large, CRKL Crk-like protein, PI3 K phosphatidylinositol 3-kinase, AKT protein kinase B, MDM2 mouse double minute 2 homolog, TP53 tumor protein p53, p21WAF-1/CIP-1 cytosolic cyclin-dependent kinase inhibitor p21, SKP21 S-phase kinase-associated protein 2 inhibitor, NF-KB nuclear factor kappa-light-chain-enhancer of activated B cells, IKKK IK $\beta$ kinase, C/EBPa CCAAT/enhancerbinding protein a, GATA2 GATA binding protein 2, GRB2 the adaptor protein growth factor receptor-bound protein 2, SOS son of sevenless, MEK mitogen-activated protein kinase kinase, ERK extracellular signal-regulated kinases, hnRNP-E2 poly(rC)-binding protein E2, FOXO3a forkhead box O3, TRAIL TNF-related apoptosis-inducing ligand 
contrast, JAK2 inhibition decreases phosphorylated Y177 (p-Y177) but does not reduce levels of BCR-ABL1, suggesting that the reduction of BCR-ABL1 by JAK2 inhibition is a separate event from phosphorylation of Y177 [90]. A recent study showed that absence of JAK2 in a CML-CP model drastically accelerated disease development with increased numbers of WBC counts and severe splenomegaly, suggesting that JAK2 inhibits the progress of CML [96].

The level of p-STAT3 is higher in CML patients who are resistant to imatinib treatment than in patients who respond [97]. BCR-ABL1 regulates transcription of STAT3 by phosphorylating JAK1/2 and mitogen-activated protein kinase kinase (MEK) [98]. Both STAT3 and STAT $5 \mathrm{a} / \mathrm{b}$ are essential for the induction of CMLlike leukemia by BCR-ABL1 and for the maintenance of the survival and growth of CML cells [95]. STAT5- or STAT3-knockout mice with BCR-ABL1 fail to display a CML phenotype and prevent established B-ALL. Additionally, STAT5, not STAT3, is essential for cell cycle progression and survival of lymphoid leukemic cells [95]. The N-terminal of STAT5a/b plays a key role in B-lymphoid transformation [99]. Furthermore, STAT5 is not essential for normal hematopoiesis $[95,100]$, which makes it a good therapeutic target in Ph-positive leukemia $[84,85]$.

\section{The PI3K-AKT-mTOR pathway}

The PI3K-AKT-mammalian target of rapamycin (mTOR) pathway is another important downstream cascade in Ph-positive leukemia, including CML and ALL. It is able to activate c-kit-positive HSCs from the quiescent to the proliferative state in BCR-ABL1-positive CML [101]. Through a PI3K-AKT-mTOR-independent pathway, BCR-ABL1 evades cell cycle arrest by increasing cytosolic cyclin-dependent kinase inhibitor p21 (p21WAF-1/ CIP-1), which has been reported to have a pro-survival role localizing in cytoplasm [102]. BCR-ABL1 also induces S-phase kinase-associated protein 2 (Skp2) expression to promote proliferation of CML cells by the PI3K-AKT-mTOR pathway [103]. Meanwhile, BCRABL1 increases glucose metabolism and activates mitochondrial electron transport chains specifically regulated by PI3K-AKT-mTOR in CML cells $[104,105]$. Ablation of PI3 K prevents BCR-ABL1 leukemogenesis in mice, and a dual PI3 K/mTOR inhibitor PI-103 suppresses proliferation of mouse pre-B-ALL more effectively than rapamycin [106]. The dual PI3 K and mTOR small-molecule inhibitors are also effective against TKI-resistant BCRABL1 mutant cells in vivo and in vitro [107]. In addition, inhibition of PI3K shows synergy with TKI-enhancing cytotoxic effects in $\mathrm{p} 210^{\text {BCR-ABL1 }}$-transformed cells, especially apoptosis $[107,108]$. Taken together, these findings suggest that the PI3K-AKT-mTOR pathway plays an important role in BCR-ABL1-mediated leukemogenesis.

Currently, several PI3K inhibitors are being investigated, and several clinical trials have been completed in pediatric ALL [109]. Interestingly, a recent study showed that PI3K inhibitors induced global transcriptional reprogramming in tumors, with (re)phosphorylation of AKT and mTOR, and increased tumor cell motility and invasion [110]. That might explain why PI3K inhibitors were not more clinically efficacious in the last 10 years. Therefore, combining PI3K inhibitors with other therapeutic approaches may be a promising future therapeutic strategy.

\section{The MAPK/ERK (RAS/RAF/MEK/ERK) pathway}

The RAS/RAF/MEK/extracellular signal-regulated kinases (ERK) pathway is a central signal transduction pathway, which transmits signals from cell surface receptors to nuclear transcription factors. In BCR-ABL1-positive leukemia cells, activation of the RAS/RAF/MEK/ERK pathway results in uncontrolled proliferation [111113]. BCR-ABL1 transduces proliferative signals partly through activation of RAS via GRB2/GRB2-associated binding protein 2 (GAB2) phosphorylation dependent on phosphorylation of Y177 of BCR [31, 114]. Disruption of RAS signaling attenuates development of BCR-ABL1induced CML-like disease in mice, but most BCR-ABL1positive mice with mutant $R A S$ eventually develop pro-B-ALL. This indicates that RAS is a critical target of BCR-ABL1 in the pathogenesis of CML but not B-ALL [115].

Blockage of MEK/ERK elevates cytotoxicity of histone deacetylase inhibitors in BCR-ABL1-expressing cells resistant to the TKIs gefitinib or imatinib and leads to erythroid differentiation [116, 117]. BCR-ABL1 also activates $B-R A F$ kinase, which is an effector molecule of the RAS-related protein RAP1 and a potent activator of the MEK/ERK/ELK-1 signaling pathway. Inhibition of RAP1 activation inhibits the BCR-ABL1-induced activation of ERK-1 [113].

Leukemic microenvironment plays a role in promoting and maintaining leukemic cell proliferation and survivability [118]. In addition to BCR-ABL1 kinase activity, CML stem cell survival depends on the continuous support of the hematopoietic niche [84]. Osteopontin (OPN), a component of the stem cell niche, is overexpressed in BCR-ABL1-expressing cells. BCR-ABL1 induces OPN overexpression by activating a signaling cascade involving RAS, RAF-1, and MAPK, indicating that BCR-ABL1 maintains the microenvironment for leukemia stem cells possibly through the RAS/RAF/MEK/ ERK pathway [119]. 
Interestingly, oncogene addiction analysis shows that due to MEK-dependent negative feedback, JAK2 plays little or no role in signal transduction when BCR-ABL1 is active. After prolonged BCR-ABL1 inhibition (more than $8 \mathrm{~h}$ ), negative feedback is relieved and JAK2 becomes critically important as a mediator of STAT5 phosphorylation in the downstream pathways [120]. Maintaining negative feedback with oncoprotein inhibition may, therefore, best facilitate the effects of target agents.

\section{TRAIL-induced apoptosis}

Tumor necrosis factor (TNF)-related apoptosis-inducing ligand-TNFSF10 (TRAIL), a death receptor ligand, is down-regulated in BCR-ABL1-positive leukemia [121123]. In BCR-ABL1-positive cell lines and primary ALL cells, TRAIL induces death-inducing receptor (DR4 and DR5)-dependent apoptotic cell death [124]. Treatment with imatinib enhances TRAIL-induced apoptosis [125, 126]. Inducing TRAIL-mediated cell death also inhibits cancer cell proliferation and suppresses growth of CML xenografts [127].

These results suggest the potential use of recombinant TRAIL as a novel therapeutic agent; they also suggest the possible contribution of endogenously expressed TRAIL in immunotherapy against BCR-ABL1-positive leukemia.

\section{C/EBPa-mediated differentiation}

CCAAT/enhancer-binding proteins (C/EBPs) are transcription factors that regulate normal myelopoiesis as well as myeloid disorders. BCR-ABL1 suppresses $C / E B P \alpha$ mRNA levels via the induction of the mitogen-activated protein kinases-poly $(\mathrm{rC})$-binding protein E2 (MAPKhnRNP-E2) pathway [128-130]. Disruption of C/EBP $\alpha$ blocks the transition from common myeloid to granulocyte-monocyte progenitor cells [131]. The failure of myeloid precursors to differentiate into mature granulocytes is a unique characteristic of clinical progression from CML-CP to CML-BC. C/EBP $\alpha$ expression is reduced in BCR-ABL1-expressing cell lines and CML-BC cells. Loss of miR-328 in CML-BC also reduces expression of $\mathrm{C} / \mathrm{EPB} \alpha$ [132]. Meanwhile, phosphorylation at serine 21 of the $\mathrm{C} /$ $\mathrm{EBP} \alpha$ protein is associated with differentiation effects in K562 cells [133]. Furthermore, C/EBP $\alpha$ deregulation and neutrophilic differentiation by BCR-ABL1 are reversed by imatinib [134]. The gene profile shows that activation of $\mathrm{C} /$ EBP $\alpha$ induces the expression of cell cycle- and apoptosisrelated genes and enhances imatinib-induced apoptosis of K562 cells [135]. Restoration of C/EBP $\alpha$ expression induces terminal granulocytic differentiation and inhibits proliferation of leukemia cells in vitro and in vivo [136-138]. Moreover, the effects of $\mathrm{C} / \mathrm{EBP} \alpha$ in $\mathrm{p} 210^{\mathrm{BCR}-\mathrm{ABL} 1}$-expressing cells depend partly on transcriptional repression of c-MYC and GATA-2 [139]. However, absence of C/EBP $\alpha$ results in loss of myeloid identity in transgenic mice with BCR-ABL1induced CML-like disease and, interestingly, causes erythroleukemia instead, suggesting that CEBPa is essential for BCR-ABL1-positive CML [140].

Ectopic expression of $\mathrm{C} / \mathrm{EBP} \alpha$ in primary human $\mathrm{BCR}$ ABL1-positive B-ALL cells induces macrophage-like cells, which are unable to establish disease in xenograft hosts [141]. Epigenetic studies show that aberrant methylation in the $\mathrm{CpG}$ island of the promoter region of $\mathrm{C} /$ $E B P \alpha$ is a common event in CML, suggesting that regulating methylation of $C / E B P \alpha$ could be a new therapeutic direction for treating Ph-positive leukemia [142].

\section{Autophagy}

Autophagy can be manipulated for a better therapy on AML by inducing cooperation with apoptosis and differentiation [143]. Also, autophagy presents a potential target in BCR-ABL1-positive leukemia, particularly in TKI-resistant types [144-146]. Disruption of autophagy is a new strategy to treat imatinib-resistant CML patients. Pharmacologic or genetic inhibition of the Hedgehog pathway can markedly induce autophagy in BCR-ABL1-positive CML cells. Inhibition of both Hedgehog pathway and autophagy may be a potent new strategy to overcome drug resistance in CML [147]. Importantly, BCR-ABL1 suppresses apoptosis as well as autophagy, resulting in low basal levels of autophagy in BCR-ABL1-transformed cells. Treatment of BCR-ABL1-positive cells in vitro with chemical inhibitors of autophagy or by deletion of the autophagyrelated 3 (Atg3) gene induces cell death. In a cell transfer model in vivo, Atg3 deletion also prevented BCR-ABL1mediated leukemogenesis [148]. Moreover, the therapeutic drug arsenic trioxide $\left(\mathrm{As}_{2} \mathrm{O}_{3}\right)$ targeted BCR-ABL1 for autophagy degradation via a p62/the gene encoding p62 (SQSTM1)-dependent mechanism, which is mediated localization of the oncoprotein to the autolysosomes [149].

In conclusion, BCR-ABL1-positive cells particularly depend on autophagy for leukemogenesis, and regulation of autophagy may be a therapeutic approach for BCRABL1-positive leukemia.

\section{Genomic instability}

Genomic instability is an essential factor of tumorigenesis for both leukemias and solid tumors. Chromosomal translocations generate the aberrant fusion TKs, such as BCR-ABL1, Ets variant gene 6-ABL1 [TEL(ETV6)/ ABL1], TEL(ETV6)/JAK2, and TEL-platelet-derived growth factor beta receptor [TEL(ETV6)/PDGF $\beta R$ ], which induce hematologic malignancies [150]. BCRABL1-positive cells contain elevated numbers of DNA double-strand breaks (DSBs) and show stimulation of the single-strand annealing (SSA) repair process [151-153]. The WRN gene (mutated in Werner syndrome) encodes 
a helicase required for processing DSB ends during the repair. BCR-ABL1 enhances the expression and increases the nuclear localization of WRN to promote survival and genomic instability [154].

Prolonged expression of the $\mathrm{p} 210^{\mathrm{BCR}-\mathrm{ABL} 1}$ transcript was associated with development of aneuploidy and complex chromosomal translocations in the mouse model [155]. Transgenic mice expressing p190 ${ }^{\text {BCR-ABL1 }}$ developed karyotypic abnormalities, most commonly trisomies involving chromosomes 12,14 , or 17 , alone or in combination [18].

A recent study using a whole transcriptome array showed that genes such as dipeptidyl peptidase-4 (DPP4), interleukin-2 receptor alpha (IL2RA), protein tyrosine phosphatase, receptor type D (PTPRD), calcium channel, voltage-dependent, L type, alpha 1D subunit (CACNA1D), interleukin 1 receptor accessory protein (IL1RAP), solute carrier family 4 (SLC4A4), and potassium channel, subfamily $\mathrm{K}$, member 5 (KCNK5) were up-regulated in BCR-ABL1-positive CML. This study found that these genes play key roles in proliferation, differentiation, and molecular pathways in HSCs [156]. Accumulation of additional cytogenetic and molecular abnormalities also contributes to blast transformation and progression [157-159]. BCR-ABL1 and genomic instability are currently considered to be a complex partnership in leukemogenesis, suggesting that BCR-ABL1 itself leads to genomic instability independent of its leukemogenic effect [20].
The $\mathrm{Ph}$ rarely appears with other genetic abnormalities in CML-CP. However, in Ph-positive B-ALL, AML, MPAL, and CML-AP and CML-BP, deletions involving immunoglobulin heavy chain $(I G H)$, T-cell receptor $(T C R)$, encoding the transcription factor IKAROS family zinc finger protein 1 (IKZF1), and cyclin-dependent kinase inhibitor $2(C D K N 2 A / B)$ are common [66]. A recent study showed that the $B C R-A B L 1$ fusion gene could be a prenatal and possibly initiating genetic event in Ph-positive childhood ALL and that variation in other genes is a secondary and probably postnatal event in these cases [160]. Common gene abnormalities found in $\mathrm{Ph}$-positive leukemia are discussed in Table 1.

\section{IKZF1 mutation}

$I K Z F 1$, located on chromosome $7 \mathrm{p} 12$, is a regulator of lymphocyte differentiation. Wild-type IKAROS prevents stemness properties and has tumor suppressor activity in BCR-ABL1-initiated leukemia [161]. BCR-ABL1 and $I K Z F 1$ mutations are strongly linked: somatic mutations in $I K Z F 1$ are present in $70 \%-83 \%$ of Ph-positive ALL cases; approximately $90 \%$ are deletions, and $10 \%$ are point mutations [162]. Deletion of IKZF1 has also been identified as an acquired lesion at transformation from CML-CP to lymphoid CML-BC but never in myeloid CML-BC or AML with Ph [163]. In addition, loss of IKZF1 predicts a poor prognosis in patients with $\mathrm{Ph}$ positive leukemia [164]. Disruption of IKAROS activity in primitive CML-CP cells can mimic myeloid disease

Table 1 Recurrent genomic abnormalities in Philadelphia chromosome (Ph)-positive leukemia

\begin{tabular}{|c|c|c|c|c|c|}
\hline Genomic abnormality & Location & Status & Ph-positive leukemia & Frequency & Reference(s) \\
\hline \multirow[t]{2}{*}{$\mid K Z F 1$} & $7 q 12.2$ & Deletion & $\mathrm{ALL}$ & $50 \%-83 \%$ & {$[162,164]$} \\
\hline & & Deletion & Lymphoid CML-BC & $73 \%-75 \%$ & {$[163,180]$} \\
\hline \multirow[t]{2}{*}{$P A \times 5$} & $9 p 13$ & Deletion & $A L L$ & $33 \%-51 \%$ & {$[171,172,180]$} \\
\hline & & Deletion & Lymphoid CML-BC & $58.3 \%$ & {$[180]$} \\
\hline$E B F 1$ & $5 q 34$ & Deletion & $\mathrm{ALL}$ & $14 \%$ & [198] \\
\hline \multirow[t]{4}{*}{$C D K N 2 A / B$} & 9p13-p23.1 & Deletion & $\mathrm{AML}$ & $50 \%$ & {$[66]$} \\
\hline & & Deletion & MPAL & $33.3 \%$ & {$[66]$} \\
\hline & & Deletion & $\mathrm{ALL}$ & $53.5 \%$ & {$[163,164]$} \\
\hline & & Deletion & Lymphoid CML-BC & $58.3 \%-69 \%$ & {$[180]$} \\
\hline \multirow[t]{2}{*}{ IG } & $14 q 32.33$ & IGHV/IGHG2 M deletion & Lymphoid CML-BC & $66 \%-100 \%$ & {$[66,163,180]$} \\
\hline & $22 q 11.2$ & IGLL1 deletion & $\mathrm{AML}$ & $66.7 \%$ & {$[66]$} \\
\hline \multirow[t]{2}{*}{$T C R$} & $14 q 11.2 / 7 p 14.1$ & TCRA/B/D deletion & AML/MPAL & $66.7 \%$ & {$[66]$} \\
\hline & $14 q 11.2$ & TCRA deletion & Lymphoid CML-BC & $74 \%$ & {$[66,180]$} \\
\hline \multirow[t]{3}{*}{ BTG1 } & $12 q 21.33$ & Deletion & BCP-ALL & $11 \%-31.3 \%$ & {$[176]$} \\
\hline & & Deletion & MPAL & $33.3 \%$ & {$[176]$} \\
\hline & & Deletion & CML-BC (B-lineage) & $33.3 \%$ & {$[176]$} \\
\hline
\end{tabular}

IKZF1 transcription factor IKAROS family zinc finger protein 1, PAX5 paired box 5, EBF1 early B-cell factor 1, CDKN2A/B cyclin-dependent kinase inhibitor 2, IG immunoglobulin, TCR T-cell receptor, BTG1 B-cell translocation gene 1, IGHV immunoglobulin heavy chain variable region, IGHG2M immunoglobulin heavy constant gamma 2, IGLL1 immunoglobulin lambda-like polypeptide 1, TCRA T-cell receptor alpha locus, $A L L$ acute lymphoblastic leukemia, CML-BC chronic myeloid leukemia blast crisis, $A M L$ acute myeloid leukemia, MPAL mixed-phenotype acute leukemia, BCP-ALL B-cell precursor ALL 
progression (CML-AP), revealing that loss of IKAROS is a frequent step and potential predictor of BCR-ABL1positive CML-AP/BC [162]. The IKAROS-6 (IK6) is produced by an in-frame deletion of exons 4-7 of IKZF1, which deletes the DNA-binding domain and leads to cytosolic accumulation of the mutant protein. The mutations associated with a more profound reduction in IKAROS function (bi-allelic deletion and IK6) are particularly common in Ph-positive ALL [165].

In addition, loss of $I K Z F 1$ is recurrent in pediatric AML and may be a determinant of oncogenesis in AML with monosomy 7 [166]. Sequencing of IKZF1 deletion breakpoints suggests that aberrant recombination activating gene (RAG)-mediated $\mathrm{V}(\mathrm{D}) \mathrm{J}$ recombination is responsible for the deletions [167].

\section{$P A X 5$ and EBF1 mutation}

The paired box 5 (PAX5) and early B-cell factor 1 (EBF1) are transcription factors that are expressed specifically during B-cell development and control lineage identity and commitment [168-170]. Recurrent deletions of PAX5 and EBF1 occur in approximately $50 \%$ and $14 \%$ of Ph-positive ALL cases, respectively $[163,168,171]$. In contrast to BCR-ABL1-negative ALL, no point mutations of PAX5 have been found, suggesting that deletions are the main mechanism of inactivation of $P A X 5$ in BCRABL1-positive ALL [172]. EBF1 co-regulates target genes with PAX5. In mouse models, loss of PAX5 or EBF1 leads to a differentiation block at the pro- to pre-B-cell stage, resulting in B-cell precursor leukemia (BCP-ALL) [170, 173]. Complete loss of $P A X 5$ and EBF1 is apparently a secondary event and is significantly associated with $B C R$ ABL1 [171].

\section{BTG1 deletion}

The B-cell translocation gene 1 (BTG1) on chromosome $12 \mathrm{q} 21.33$ is highly conserved and belongs to an antiproliferative gene family that regulates cell growth, differentiation, and angiogenesis [174, 175]. BTG1 deletion occurs in $11 \%-31.3 \%$ of BCP-ALL cases, in $33.3 \%$ of MPAL cases, and in 33.3\% of CML-BC (B-lineage) cases [176]. Eight distinct deletions of different sizes within the second exon of BTG1 have been identified in BCP-ALL, resulting in the expression of truncated BTG1 transcripts [177]. Loss of BTG1 expression also causes glucocorticoid (GC) resistance both by reducing glucocorticoid receptor (GR) expression and by controlling GR-mediated transcription in ALL [178]. It suggests that BTG1 deletions may act as "drivers" of leukemogenesis in BCPALL, MPAL, and lymphoid CML-BC (B-lineage) with Ph. BTG1 overexpression inhibits proliferation and invasion and induces $\mathrm{G}_{2} / \mathrm{M}$ arrest, differentiation, senescence, and apoptosis in xenograft models of gastric cancer. Restoring
BTG1 might reverse phenotypes and be a potential target for gene therapy of Ph-positive leukemia [179].

\section{IGH and TCR deletion}

The deletions of 4 chromosomal regions, $7 \mathrm{p} 12-14$, 9p21-24, 14q11.2, and 14q32.33, are found recurrently in Ph-positive leukemia. The deletions of immunoglobulin heavy chain $(I g H)$ genes and $T C R \alpha / \beta / \gamma$ genes are restricted to the four chromosomal regions. Most common deletions include immunoglobulin heavy chain variable region $(I G H V)$, immunoglobulin heavy constant gamma 2 (IGHG2 $M$ ), and T-cell receptor alpha locus (TCRA). Deletion within both IGH and TCR genes is a characteristic of lymphoid CML-BC with $\mathrm{Ph}$; none of these genome losses is detected in CML-CP or myeloid CML-BC samples [180]. Deletions within chromosomes 7 and 9 , including $I K Z F 1$ and $C D K N 2 a / b$ genes, are also frequently accompanied by $I G H$ and $T C R$ gene deletion in Ph-positive BP-ALL [66], indicating that deletion of the $I G H$ and/or $T C R$ gene region is obligatory for the development of a malignant clone with a lymphoid phenotype. Interestingly, Ph-positive AML also possesses deletions of immunoglobulin $(I G)$ and $T C R$ genes but involving immunoglobulin lambda-like polypeptide 1 (IGLL1, 22q11.2) and TCRA/B/D (14q11.2 and 7p14.1), respectively. The above studies suggested that different parts of the deletion with $I G$ and $T C R$ genes might result in different phenotypes of leukemia $[19,66,163]$.

\section{Therapeutic resistance and disease progression in $\mathrm{Ph}$-positive leukemia patients}

Compared with CML-CP patients, imatinib responses are much less durable in patients with CML-AP/BC or ALL [8-10]. Compelling research suggests that a population of cancer stem cells (CSCs) is responsible for therapeutic resistance and disease progression. BCR-ABL1-positive stem cells persist in CML patients despite prolonged treatment with imatinib [181, 182]. Primitive, quiescent, $\mathrm{Ph}$-positive stem cells $\left(\mathrm{CD} 34^{+} \mathrm{CD} 38^{-}\right)$from patients with CML are insensitive to imatinib in vitro [183]. Consistently, the BCR-ABL1 expression in persistent leukemic stem cells could explain innate resistance to imatinib and to other TKIs [184].

In CML patients with TKI resistance, relapse or evolving to blast crisis, BCR-ABL1 kinase mutations (M237I, L248V, Q252E, Y253H, D276G, G321E, V304A, M351T, T315 I, E352G, Y353G, E373G, and T389A) can be detected in stem cells $[185,186]$. Mutations were found in $27 \%$ of CML-CP patients, $52 \%$ of CML-AP patients, $75 \%$ of myeloid blast crisis patients, and $83 \%$ of lymphoid blast crisis/Ph-positive ALL patients [187]. Thirty percent of patients with primary resistance and $57 \%$ of patients with acquired resistance were associated with these 
mutations [187]. Studies have confirmed that the mutations were the potential source of resistance and relapse [185]. The following mutations are involved in theraputic resistence and disease progression [188]: (1) contact residues (such as T315) by impeding inhibitor access or eliminating critical hydrogen bonds; (2) the ATP-binding loop (such as L248V) by preventing Abl from adopting the specific conformation required for high-affinity imatinib binding; and (3) regulatory motifs (such as the activation loop) by stabilizing an active conformation that is inaccessible to imatinib.

Recent studies showed that inhibition of heat shock protein 90 (Hsp90) decreased the number of leukemia stem cells, caused BCR-ABL protein degradation by the ubiquitin-proteasome pathway, and prolonged survival of mice with CML induced by BCR-ABL-T315I [189, 190]. Many novel Hsp90 inhibitors have entered into clinical trials, the results of which are encouraging [190]. This anti-Hsp90 strategy in treating CML patients, especially with TKI resistance, has a good application prospect. Another study showed that some alkyne-containing pyrazolopyrimidines can inhibit not only Abl(T315I) in vitro but also Bcr-Abl(T315I) in cells, suggesting that these pyrazolopyrimidines can serve as lead compounds for targeted therapy to overcome drug resistance of CML [191]. Also, one third-generation TKI, ponatinib, has been proven against the drug resistance including the T315I mutation. X-ray crystallographic analysis revealed that ponatinib inactivated T315I Bcr-Abl mutated kinase by conformational alteration [192].

In brief, a quiescent population of leukemia stem cells with or without $B C R-A B L 1$ kinase domain mutations is responsible for drug resistance [11].

\section{Conclusion leukemogenesis is an outcome of the Ph combined with other genetic variations}

Expression of $B C R-A B L 1$ (p210 transcript) has been detected at very low levels in the peripheral blood cells of some healthy individuals but not in umbilical cord blood cells [193]. In addition, $B C R-A B L 1$-specific T cells are detected in healthy donors and in CML patients after allogeneic stem cell transplantation [194]. These results indicate that normal cells evolve progressively to a neoplastic state, and they may acquire a succession of genetic abnormalities and gain the ability to maintain proliferation, inhibit differentiation, and resist cell death [195].

The $\mathrm{Ph}$ bearing the $B C R-A B L 1$ fusion gene is the key initiator of different phenotypes of leukemia with diverse prognoses. The translocation leads to persistent TK activation and genomic instability during leukemogenesis. Disorders in multiple signaling pathways and genetic abnormalities combined with the $\mathrm{Ph}$ are essential for the evolution of different types of leukemia; however, why cells possessing the $\mathrm{Ph}$ should evolve specifically into CML, AML, ALL, or MPAL is currently unclear and under investigation. Evidence shows that there are characteristics exclusive to specific leukemias, including deletion of BTG1 in B-cell leukemia, loss of IKZF1 with monosomy 7 in AML, and deletions involving IGH, TCR, IKZF1, and $C D K N 2 A / B$ in CML-AP/CP. Greater understanding of leukemogenesis and the effect of treatment on clonal evolution will provide novel insights into the design of future therapeutic strategies for Ph-positive leukemia [196, 197].

\begin{abstract}
Abbreviations
Ph: Philadelphia chromosome; CML: chronic myeloid leukemia; ALL: acute lymphoblastic leukemia; AML: acute myeloid leukemia; MPAL: mixed-phenotype acute leukemia; TK: tyrosine kinase; TKIs: tyrosine kinase inhibitors; CML-N neutrophilic-chronic myeloid leukemia; Y177: phosphorylated tyrosine 177; CML-CP: chronic phase of CML; CML-AP: accelerated phase of CML; CML-BC: blast crisis of CML; myeloid CML-BC: myeloid-BC of CML; HSC: hematopoietic stem cell; MPD: myeloproliferative disorder; OPN: osteopontin; TRAIL: tumor necrosis factor-related apoptosis-inducing ligand-TNFSF10; C/EBPs: CCAAT/ enhancer-binding proteins; SSA: single-strand annealing; IKZF1: encoding the transcription factor IKAROS; BTG1: B cell translocation gene 1; IGH: immunoglobulin heavy chain; EBF1: early B-cell factor 1; PAX5: paired box 5; CDKN2A/B: cyclin-dependent kinase inhibitor 2; TCR: T-cell receptor; IGHV: immunoglobulin heavy chain variable region; IGHG2M: immunoglobulin heavy constant gamma 2; TCRA: T-cell receptor alpha locus; IGLL1: immunoglobulin lambdalike polypeptide 1 .
\end{abstract}

\section{Authors' contributions}

QL, JSY, and ZJK conceived of the study. ZJK, LZX, ZJL, and DH participated in its design and coordination. ZJK drafted the manuscript. YY, YFL, BL, and JXF reviewed and edited the manuscript. ZJK and YJP performed the diagrammatic drawing. All authors read and approved the final manuscript.

\section{Author details \\ ${ }^{1}$ Department of Hematology, The Second Affiliated Hospital, Institute of Can- cer Stem Cell, Dalian Medical University, Dalian 116023, Liaoning, P. R. China. ${ }^{2}$ State Key Laboratory of Oncology in South China, Sun Yat-sen University Cancer Center, Guangzhou 510060, Guangdong, P. R. China. ${ }^{3}$ Department of Oncology, The Second Affiliated Hospital, Dalian Medical University, Dalian 116023, Liaoning, P. R. China. ${ }^{4}$ Department of Hematology, The Third Affiliated Hospital, Sun Yat-sen University, Guangzhou 510630, Guangdong, P. R. China.}

\section{Acknowledgements}

We thank Professor Han Liu for revising the manuscript. This study was supported by the China Central Budget Recruitment Program of High-Level Overseas Talent (GDW 201221022066 to Q. Liu), the National Basic Research Program of China (973 Program: No. 2012CB967000 to Q. Liu), the National Natural Science Foundation of China (NNSF No. 81130040 to Q. Liu and No. 81201686 to J. Xu), the Program for Changjiang Scholars and Innovative Research Team in Universities (ITR 13049 to Q. Liu), and the Liaoning (NSF 2014029102 to Q. Liu).

\section{Competing interests}

The authors declare that they have no competing interests.

Received: 25 October 2015 Accepted: 3 May 2016

Published online: 27 May 2016

\section{References}

1. Chen W, Zheng R, Zeng H, Zhang S. The updated incidences and mortalities of major cancers in China, 2011. Chin J Cancer. 2015;34(3):53. 
2. Siegel RL, Miller KD, Jemal A. Cancer statistics, 2015. CA Cancer J Clin. 2015;65(1):5-29.

3. Nowell PC. A minute chromosome in human chronic granulocytic leukemia. Science. 1960;132:497-501.

4. Rowley JD. New consistent chromosomal abnormality in chronic myelogenous leukaemia identified by quinacrine fluorescence and Giemsa staining. Nature. 1973;243:290-3.

5. Collins SJ, Groudine MT. Rearrangement and amplification of c-abl sequences in the human chronic myelogenous leukemia cell line K-562. Proc Natl Acad Sci USA. 1983;80(15):4813-7.

6. Kurzrock R, Gutterman JU, Talpaz M. The molecular genetics of Philadelphia chromosome-positive leukemias. N Engl J Med. 1988;319(15):990-8.

7. Li S, Ilaria RL Jr, Million RP, Daley GQ, Van Etten RA. The P190, P210, and P230 forms of the BCR/ABL oncogene induce a similar chronic myeloid leukemia-like syndrome in mice but have different lymphoid leukemogenic activity. J Exp Med. 1999;189(9):1399-412.

8. Ottmann OG, Druker BJ, Sawyers CL, Goldman JM, Reiffers J, Silver RT, et al. A phase 2 study of imatinib in patients with relapsed or refractory Philadelphia chromosome-positive acute lymphoid leukemias. Blood. 2002;100(6):1965-71.

9. Sawyers CL, Hochhaus A, Feldman E, Goldman JM, Miller CB, Ottmann $\mathrm{OG}$, et al. Imatinib induces hematologic and cytogenetic responses in patients with chronic myelogenous leukemia in myeloid blast crisis: results of a phase II study. Blood. 2002;99(10):3530-9.

10. Tojo A, Usuki K, Urabe A, Maeda Y, Kobayashi Y, Jinnai I, et al. A Phase I/II study of nilotinib in Japanese patients with imatinib-resistant or -intolerant Ph + CML or relapsed/refractory Ph + ALL. Int J Hematol. 2009;89(5):679-88.

11. Corbin AS, Agarwal A, Loriaux M, Cortes J, Deininger MW, Druker BJ. Human chronic myeloid leukemia stem cells are insensitive to imatinib despite inhibition of BCR-ABL activity. J Clin Invest. 2011;121(1):396-409.

12. Rafiei A, Mian AA, Doring C, Metodieva A, Oancea C, Thalheimer FB, et al. The functional interplay between the t(9;22)-associated fusion proteins BCR/ABL and ABL/BCR in Philadelphia chromosome-positive acute lymphatic leukemia. PLoS Genet. 2015;11(4):e1005144.

13. Zhang $L J$, Gan $Y M$, Yu L. Occurrence of BCR/ABL fusion gene in a patient with acute promyelocytic leukemia. Med Oncol. 2015;32(1):382.

14. Verrma SP, Dutta TK, Vinod KV, Dubashi B, Ariga KK. Philadelphia chromosome positive pre-T cell acute lymphoblastic leukemia: a rare case report and short review. Indian J Hematol Blood Transfus. 2014;30(Suppl 1):177-9.

15. Choi W, Kim M, Lim J, Han K, Lee S, Lee JW, et al. Four cases of chronic myelogenous leukemia in mixed phenotype blast phase at initial presentation mimicking mixed phenotype acute leukemia with $\mathrm{t}(9 ; 22)$. Ann Lab Med. 2014;34(1):60-3.

16. Matutes E, Pickl WF, Van't Veer M, Morilla R, Swansbury J, Strobl H, et al. Mixed-phenotype acute leukemia: clinical and laboratory features and outcome in 100 patients defined according to the WHO 2008 classification. Blood. 2011;117(11):3163-71.

17. Sabattini E, Bacci F, Sagramoso C, Pileri SA. WHO classification of tumours of haematopoietic and lymphoid tissues in 2008: an overview. Pathologica. 2010;102(3):83-7.

18. Voncken JW, Morris C, Pattengale P, Dennert G, Kikly C, Groffen J, et al. Clonal development and karyotype evolution during leukemogenesis of BCR/ABL transgenic mice. Blood. 1992;79(4):1029-36.

19. Sill H, Goldman JM, Cross NC. Homozygous deletions of the p16 tumor-suppressor gene are associated with lymphoid transformation of chronic myeloid leukemia. Blood. 1995;85(8):2013-6.

20. Ilaria R Jr. Bcr/Abl, leukemogenesis, and genomic instability: a complex partnership. Leuk Res. 2002;26(11):971-3.

21. Hagemeijer A. Chromosome abnormalities in CML. Baillieres Clin Haematol. 1987;1 (4):963-81

22. Score J, Calasanz MJ, Ottman O, Pane F, Yeh RF, Sobrinho-Simoes MA, et al. Analysis of genomic breakpoints in p190 and p210 BCR-ABL indicate distinct mechanisms of formation. Leukemia. 2010;24(10):1742-50.

23. Pane F, Frigeri F, Sindona M, Luciano L, Ferrara F, Cimino R, et al. Neutrophilic-chronic myeloid leukemia: a distinct disease with a specific molecular marker (BCR/ABL with C3/A2 junction). Blood. 1996;88(7):2410-4.
24. He Y, Wertheim JA, Xu L, Miller JP, Karnell FG, Choi JK, et al. The coiled-coil domain and Tyr 177 of bcr are required to induce a murine chronic myelogenous leukemia-like disease by bcr/abl. Blood. 2002;99(8):2957-68.

25. Million RP, Van Etten RA. The Grb2 binding site is required for the induction of chronic myeloid leukemia-like disease in mice by the $\mathrm{Bcr} / \mathrm{Abl}$ tyrosine kinase. Blood. 2000;96(2):664-70.

26. Maru Y, Witte ON. The BCR gene encodes a novel serine/threonine kinase activity within a single exon. Cell. 1991;67(3):459-68.

27. Pendergast AM, Gishizky ML, Havlik MH, Witte ON. SH1 domain autophosphorylation of P210 BCR/ABL is required for transformation but not growth factor independence. Mol Cell Biol. 1993;13(3):1728-36.

28. Zhang X, Subrahmanyam R, Wong R, Gross AW, Ren R. The NH(2)terminal coiled-coil domain and tyrosine 177 play important roles in induction of a myeloproliferative disease in mice by Bcr-Abl. Mol Cell Biol. 2001;21(3):840-53.

29. Beissert T, Hundertmark A, Kaburova V, Travaglini L, Mian AA, Nervi C, et al. Targeting of the $\mathrm{N}$-terminal coiled coil oligomerization interface by a helix-2 peptide inhibits unmutated and imatinib-resistant BCR/ ABL. Int J Cancer. 2008;122(12):2744-52.

30. Preyer $M$, Vigneri P, Wang JY. Interplay between kinase domain autophosphorylation and F-actin binding domain in regulating imatinib sensitivity and nuclear import of BCR-ABL. PLOS ONE. 2011;6(2):e17020.

31. Chu S, Li L, Singh H, Bhatia R. BCR-tyrosine 177 plays an essential role in Ras and Akt activation and in human hematopoietic progenitor transformation in chronic myelogenous leukemia. Cancer Res. 2007:67(14):7045-53.

32. Harnois T, Constantin B, Rioux A, Grenioux E, Kitzis A, Bourmeyster N. Differential interaction and activation of Rho family GTPases by p210bcr-abl and p190bcr-abl. Oncogene. 2003;22(41):6445-54.

33. Unwin RD, Sternberg DW, Lu Y, Pierce A, Gilliland DG, Whetton AD. Global effects of BCR/ABL and TEL/PDGFRbeta expression on the proteome and phosphoproteome: identification of the Rho pathway as a target of BCR/ABL. J Biol Chem. 2005;280(8):6316-26.

34. Burthem J, Rees-Unwin K, Mottram R, Adams J, Lucas GS, Spooncer E, et al. The rho-kinase inhibitors Y-27632 and fasudil act synergistically with imatinib to inhibit the expansion of ex vivo CD34(+) CML progenitor cells. Leukemia. 2007;21 (8):1708-14.

35. Dorey K, Engen JR, Kretzschmar J, Wilm M, Neubauer G, Schindler T, et al. Phosphorylation and structure-based functional studies reveal a positive and a negative role for the activation loop of the c-Abl tyrosine kinase. Oncogene. 2001;20(56):8075-84.

36. Schindler T, Bornmann W, Pellicena P, Miller WT, Clarkson B, Kuriyan J. Structural mechanism for STI-571 inhibition of abelson tyrosine kinase. Science. 2000;289(5486):1938-42.

37. Xu W, Harrison SC, Eck MJ. Three-dimensional structure of the tyrosine kinase c-Src. Nature. 1997;385(6617):595-602.

38. Barila D, Superti-Furga G. An intramolecular SH3-domain interaction regulates c-Abl activity. Nat Genet. 1998;18(3):280-2.

39. Nagar B, Hantschel O, Young MA, Scheffzek K, Veach D, Bornmann W, et al. Structural basis for the autoinhibition of c-Abl tyrosine kinase. Cell. 2003;112(6):859-71.

40. Grebien F, Hantschel O, Wojcik J, Kaupe I, Kovacic B, Wyrzucki AM, et al. Targeting the SH2-Kinase interface in Bcr-Abl inhibits leukemogenesis. Cell. 2011;147(2):306-19.

41. Zhang J, Adrian FJ, Jahnke W, Cowan-Jacob SW, Li AG, lacob RE, et al. Targeting Bcr-Abl by combining allosteric with ATP-binding-site inhibitors. Nature. 2010;463(7280):501-6.

42. Kantarjian HM, Keating MJ, Talpaz M, Walters RS, Smith TL, Cork A, et al. Chronic myelogenous leukemia in blast crisis. Analysis of 242 patients. Am J Med. 1987:83(3):445-54.

43. Okamoto K, Karasawa M, Sakai H, Ogura H, Morita K, Naruse T. A novel acute lymphoid leukaemia type BCR/ABL transcript in chronic myelogenous leukaemia. Br J Haematol. 1997;96(3):611-3.

44. Lichty BD, Keating A, Callum J, Yee K, Croxford R, Corpus G, et al. Expression of p210 and p190 BCR-ABL due to alternative splicing in chronic myelogenous leukaemia. Br J Haematol. 1998;103(3):711-5.

45. van Rhee F, Hochhaus A, Lin F, Melo JV, Goldman JM, Cross NC. p190 BCR-ABL mRNA is expressed at low levels in p210-positive chronic myeloid and acute lymphoblastic leukemias. Blood. 1996;87(12):5213-7. 
46. Arana-Trejo RM, Ruiz Sanchez E, Ignacio-Ibarra G, Baez de la Fuente E, Garces O, Gomez Morales E, et al. BCR/ABL p210, p190 and p230 fusion genes in 250 Mexican patients with chronic myeloid leukaemia (CML). Clin Lab Haematol. 2002;24(3):145-50.

47. Elliott SL, Taylor KM, Taylor DL, Rodwell RL, Williams BF, Shuttlewood $M M$, et al. Cytogenetic response to alpha-interferon is predicted in early chronic phase chronic myeloid leukemia by M-bcr breakpoint location. Leukemia. 1995;9(6):946-50.

48. Rozman C, Urbano-Ispizua A, Cervantes F, Rozman M, Colomer D, Feliz $P$, et al. Analysis of the clinical relevance of the breakpoint location within M-BCR and the type of chimeric mRNA in chronic myelogenous leukemia. Leukemia. 1995;9(6):1104-7.

49. Pullarkat V, Slovak ML, Kopecky KJ, Forman SJ, Appelbaum FR. Impact of cytogenetics on the outcome of adult acute lymphoblastic leukemia: results of Southwest Oncology Group 9400 study. Blood. 2008;111(5):2563-72.

50. Schultz KR, Pullen DJ, Sather HN, Shuster JJ, Devidas M, Borowitz MJ, et al. Risk- and response-based classification of childhood B-precursor acute lymphoblastic leukemia: a combined analysis of prognostic markers from the Pediatric Oncology Group (POG) and Children's Cancer Group (CCG). Blood. 2007;109(3):926-35.

51. Mrozek K, Harper DP, Aplan PD. Cytogenetics and molecular genetics of acute lymphoblastic leukemia. Hematol Oncol Clin North Am. 2009;23(5):991-1010.

52. Larson RA. Management of acute lymphoblastic leukemia in older patients. Semin Hematol. 2006;43(2):126-33.

53. Mancini M, Scappaticci D, Cimino G, Nanni M, Derme V, Elia L, et al. A comprehensive genetic classification of adult acute lymphoblastic leukemia (ALL): analysis of the GIMEMA 0496 protocol. Blood. 2005;105(9):3434-41.

54. Moorman AV, Harrison CJ, Buck GA, Richards SM, Secker-Walker LM Martineau $\mathrm{M}$, et al. Karyotype is an independent prognostic factor in adult acute lymphoblastic leukemia (ALL): analysis of cytogenetic data from patients treated on the Medical Research Council (MRC) UKALLXII/Eastern Cooperative Oncology Group (ECOG) 2993 trial. Blood. 2007;109(8):3189-97.

55. Stock W. Advances in the treatment of Philadelphia chromosomepositive acute lymphoblastic leukemia. Clin Adv Hematol Oncol. 2008;6(7):487-8

56. Melo JV. The diversity of BCR-ABL fusion proteins and their relationship to leukemia phenotype. Blood. 1996;88(7):2375-84

57. Emilia G, Luppi M, Marasca R, Torelli G. Relationship between BCR/ABL fusion proteins and leukemia phenotype. Blood. 1997;89(10):3889.

58. Roman J, Parziale A, Gottardi E, De Micheli D, Cilloni D, Tiribelli M, et al. Novel type of BCR-ABL transcript in a chronic myelogenous leukaemia patient relapsed after bone marrow transplantation. Br J Haematol. 2000;111(2):644-6.

59. Soekarman D, van Denderen J, Hoefsloot L, Moret M, Meeuwsen T, van Baal J, et al. A novel variant of the bcr-abl fusion product in Philadelphia chromosome-positive acute lymphoblastic leukemia. Leukemia. 1990;4(6):397-403.

60. Arico M, Schrappe M, Hunger SP, Carroll WL, Conter V, Galimberti S, et al. Clinical outcome of children with newly diagnosed Philadelphia chromosome-positive acute lymphoblastic leukemia treated between 1995 and 2005. J Clin Oncol. 2010;28(31):4755-61.

61. Yanada M, Ohno R, Naoe T. Recent advances in the treatment of Philadelphia chromosome-positive acute lymphoblastic leukemia. Int J Hematol. 2009:89(1):3-13.

62. Kihara R, Nagata Y, Kiyoi H, Kato T, Yamamoto E, Suzuki K, et al. Comprehensive analysis of genetic alterations and their prognostic impacts in adult acute myeloid leukemia patients. Leukemia. 2014;28(8):1586-95.

63. Ley TJ, Miller C, Ding L, Raphael BJ, Mungall AJ, Robertson AG, et al. Genomic and epigenomic landscapes of adult de novo acute myeloid leukemia. New Engl J Med. 2013;368(22):2059-74.

64. Soupir CP, Vergilio JA, Dal Cin P, Muzikansky A, Kantarjian H, Jones D, et al. Philadelphia chromosome-positive acute myeloid leukemia: a rare aggressive leukemia with clinicopathologic features distinct from chronic myeloid leukemia in myeloid blast crisis. Am J Clin Pathol. 2007:127(4):642-50.

65. Johansson B, Fioretos T, Mitelman F. Cytogenetic and molecular genetic evolution of chronic myeloid leukemia. Acta Haematol. 2002;107(2):76-94.
66. Nacheva EP, Grace CD, Brazma D, Gancheva K, Howard-Reeves J, Rai L, et al. Does BCR/ABL1 positive Acute Myeloid Leukaemia Exist? Brit J Haematol. 2013;161(4):541-50.

67. Vardiman JW, Thiele J, Arber DA, Brunning RD, Borowitz MJ, Porwit A , et al. The 2008 revision of the World Health Organization (WHO) classification of myeloid neoplasms and acute leukemia: rationale and important changes. Blood. 2009;114(5):937-51.

68. Killick S, Matutes E, Powles RL, Hamblin M, Swansbury J, Treleaven JG, et al. Outcome of biphenotypic acute leukemia. Haematologica. 1999;84(8):699-706

69. Owaidah TM, Al Beihany A, labal MA, Elkum N, Roberts GT. ACytogenetics, molecular and ultrastructural characteristics of biphenotypic acute leukemia identified by the EGIL scoring system. Leukemia. 2006;20(4):620-6.

70. Al-Seraihy AS, Owaidah TM, Ayas M, El-Solh H, Al-Mahr M, Al-Ahmari A, et al. Clinical characteristics and outcome of children with biphenotypic acute leukemia. Haematologica. 2009;94(12):1682-90.

71. Bhatia P, Binota J, Varma N, Bansal D, Trehan A, Marwaha RK, et al. A Study on the expression of BCR-ABL transcript in mixed phenotype acute leukemia (MPAL) cases using the reverse transcriptase polymerase reaction assay (RT-PCR) and its correlation with hematological remission status post initial induction therapy. Mediterr J Hematol Infect Dis. 2012;4(1):e2012024

72. Wang Y, Gu M, Mi Y, Qiu L, Bian S, Wang J. Clinical characteristics and outcomes of mixed phenotype acute leukemia with Philadelphia chromosome positive and/or bcr-abl positive in adult. Int J Hematol. 2011:94(6):552-5.

73. Daley GQ, Van Etten RA, Baltimore D. Induction of chronic myelogenous leukemia in mice by the P210bcr/abl gene of the Philadelphia chromosome. Science. 1990;247(4944):824-30

74. Heisterkamp N, Jenster G, ten Hoeve J, Zovich D, Pattengale PK, Groffen J. Acute leukaemia in bcr/abl transgenic mice. Nature. 1990;344(6263):251-3.

75. Voncken JW, Kaartinen V, Pattengale PK, Germeraad WT, Groffen J, Heisterkamp N. BCR/ABL P210 and P190 cause distinct leukemia in transgenic mice. Blood. 1995;86(12):4603-11.

76. Castellanos A, Pintado B, Weruaga E, Arevalo R, Lopez A, Orfao A, et al. $A B C R-A B L(p 190)$ fusion gene made by homologous recombination causes B-cell acute lymphoblastic leukemias in chimeric mice with independence of the endogenous bcr product. Blood. 1997;90(6):2168-74

77. Lugo TG, Pendergast AM, Muller AJ, Witte ON. Tyrosine kinase activity and transformation potency of bcr-abl oncogene products. Science. 1990;247(4946):1079-82

78. Roumiantsev S, de Aos IE, Varticovski L, Ilaria RL, Van Etten RA. The src homology 2 domain of $\mathrm{Bcr} / \mathrm{Abl}$ is required for efficient induction of chronic myeloid leukemia-like disease in mice but not for lymphoid leukemogenesis or activation of phosphatidylinositol 3-kinase. Blood. 2001;97(1):4-13.

79. Zhang X, Wong R, Hao SX, Pear WS, Ren R. The SH2 domain of bcr-Abl is not required to induce a murine myeloproliferative disease; however, SH2 signaling influences disease latency and phenotype. Blood. 2001:97(1):277-87.

80. Sattler M, Griffin JD. Molecular mechanisms of transformation by the BCR-ABL oncogene. Semin Hematol. 2003:40(Suppl 2):4-10.

81. Ilaria RL Jr, Van Etten RA. P210 and P190(BCR/ABL) induce the tyrosine phosphorylation and DNA binding activity of multiple specific STAT family members. J Biol Chem. 1996;271(49):31704-10.

82. Frank DA, Varticovski L. BCR/abl leads to the constitutive activation of Stat proteins, and shares an epitope with tyrosine phosphorylated Stats. Leukemia. 1996;10(11):1724-30.

83. Tao WJ, Lin H, Sun T, Samanta AK, Arlinghaus R. BCR-ABL oncogenic transformation of $\mathrm{NIH} 3 \mathrm{~T} 3$ fibroblasts requires the $\mathrm{L}-3$ receptor. Oncogene. 2008:27(22):3194-200.

84. Warsch W, Walz C, SexI V. JAK of all trades: JAK2-STAT5 as novel therapeutic targets in BCR-ABL1 + chronic myeloid leukemia. Blood. 2013;122(13):2167-75

85. Valent P. Targeting the JAK2-STAT5 pathway in CML. Blood. 2014;124(9):1386-8.

86. Baird AM, Lucas JA, Berg LJ. A profound deficiency in thymic progenitor cells in mice lacking Jak3. J Immunol. 2000;165(7):3680-8. 
87. Grossman WJ, Verbsky JW, Yang L, Berg LJ, Fields LE, Chaplin DD, et al. Dysregulated myelopoiesis in mice lacking Jak3. Blood. 1999;94(3):932-9.

88. Thomis DC, Gurniak CB, Tivol E, Sharpe AH, Berg LJ. Defects in B lymphocyte maturation and T lymphocyte activation in mice lacking Jak3. Science. 1995;270(5237):794-7.

89. Nosaka T, van Deursen JM, Tripp RA, Thierfelder WE, Witthuhn BA, McMickle AP, et al. Defective lymphoid development in mice lacking Jak3. Science. 1995;270(5237):800-2.

90. Samanta A, Perazzona B, Chakraborty S, Sun X, Modi H, Bhatia R, et al. Janus kinase 2 regulates $\mathrm{Bcr}-\mathrm{Abl}$ signaling in chronic myeloid leukemia. Leukemia. 2011;25(3):463-72.

91. Xie S, Lin H, Sun T, Arlinghaus RB. Jak2 is involved in C-Myc induction by Bcr-Abl. Oncogene. 2002;21(47):7137-46.

92. Sawyers $C L$. The role of myc in transformation by BCR-ABL. Leuk Lymphoma. 1993;11(Suppl 1):45-6.

93. Stella S, Tirro E, Conte E, Stagno F, Di Raimondo F, Manzella L, et al. Suppression of survivin induced by a BCR-ABL/JAK2/STAT3 pathway sensitizes imatinib-resistant CML cells to different cytotoxic drugs. Mol Cancer Ther. 2013;12(6):1085-98.

94. Fang ZH, Dong CL, Chen Z, Zhou B, Liu N, Lan HF, et al. Transcriptional regulation of survivin by c-Myc in BCR/ABL-transformed cells: implications in anti-leukaemic strategy. J Cell Mol Med. 2009;13(8B):2039-52.

95. Hoelbl A, Schuster C, Kovacic B, Zhu B, Wickre M, Hoelzl MA, et al. Stat5 is indispensable for the maintenance of bcr/abl-positive leukaemia. EMBO Mol Med. 2010;2(3):98-110.

96. Grundschober E, Hoelbl-Kovacic A, Bhagwat N, Kovacic B, Scheicher R, Eckelhart E, et al. Acceleration of Bcr-Abl + leukemia induced by deletion of JAK2. Leukemia. 2014;28(9):1918-22.

97. Sayed D, Badrawy H, Gaber N, Khalaf MR. p-Stat3 and bcr/abl gene expression in chronic myeloid leukemia and their relation to imatinib therapy. Leuk Res. 2014;38(2):243-50.

98. Coppo P, Flamant S, De Mas V, Jarrier P, Guillier M, Bonnet ML, et al. BCR-ABL activates STAT3 via JAK and MEK pathways in human cells. Br J Haematol. 2006;134(2):171-9.

99. Hoelbl A, Kovacic B, Kerenyi MA, Simma O, Warsch W, Cui Y, et al. Clarifying the role of Stat5 in lymphoid development and Abelson-induced transformation. Blood. 2006;107(12):4898-906.

100. Walz C, Ahmed W, Lazarides K, Betancur M, Patel N, Hennighausen $L$, et al. Essential role for Stat $5 a / b$ in myeloproliferative neoplasms induced by BCR-ABL1 and JAK2(V617F) in mice. Blood. 2012;119(15):3550-60.

101. Li Q, Wu Y, Fang S, Wang L, Qi H, Zhang Y, et al. BCR/ABL oncogeneinduced PI3 K signaling pathway leads to chronic myeloid leukemia pathogenesis by impairing immuno-modulatory function of hemangioblasts. Cancer Gene Ther. 2015;22(5):227-37.

102. Keeshan K, Cotter TG, McKenna SL. Bcr-Abl upregulates cytosolic p21WAF-1/CIP-1 by a phosphoinositide-3-kinase (PI3 K)-independent pathway. Br J Haematol. 2003;123(1):34-44.

103. Andreu EJ, Lledo E, Poch E, Ivorra C, Albero MP, Martinez-Climent $J A$, et al. BCR-ABL induces the expression of Skp2 through the PI3 K pathway to promote $\mathrm{p} 27 \mathrm{Kip} 1$ degradation and proliferation of chronic myelogenous leukemia cells. Cancer Res. 2005;65(8):3264-72.

104. Kim JH, Chu SC, Gramlich JL, Pride YB, Babendreier E, Chauhan D, et al. Activation of the PI3 K/mTOR pathway by BCR-ABL contributes to increased production of reactive oxygen species. Blood. 2005;105(4):1717-23.

105. Naughton R, Quiney C, Turner SD, Cotter TG. Bcr-Abl-mediated redox regulation of the PI3 K/AKT pathway. Leukemia. 2009;23(8):1432-40.

106. Kharas MG, Janes MR, Scarfone VM, Lilly MB, Knight ZA, Shokat KM, et al. Ablation of PI3 K blocks BCR-ABL leukemogenesis in mice, and a dual PI3 K/mTOR inhibitor prevents expansion of human BCR-ABL + leukemia cells. J Clin Invest. 2008;118(9):3038-50.

107. Okabe S, Tauchi T, Tanaka Y, Kitahara T, Kimura S, Maekawa T, et al. Efficacy of the dual PI3 K and mTOR inhibitor NVP-BEZ235 in combination with nilotinib against BCR-ABL-positive leukemia cells involves the ABL kinase domain mutation. Cancer Biol Ther. 2014;15(2):207-15.

108. Rioux-Bilan A, Daubon T, Morel F, Kitzis A, Bourmeyster N. Inhibition of PI3 K synergistically enhances the apoptotic effect of STI-571 on p210(bcr-abl)-transformed cells in a Rac1-dependent manner. Leuk Res. 2008;32(3):517-9.
109. Barrett D, Brown VI, Grupp SA, Teachey DT. Targeting the PI3 K/AKT/ mTOR signaling axis in children with hematologic malignancies. Paediatr Drugs. 2012;14(5):299-316.

110. Caino MC, Ghosh JC, Chae YC, Vaira V, Rivadeneira DB, Faversani A, et al. PI3 K therapy reprograms mitochondrial trafficking to fuel tumor cell invasion. Proc Natl Acad Sci USA. 2015;112(28):8638-43.

111. Steelman LS, Pohnert SC, Shelton JG, Franklin RA, Bertrand FE, McCubrey JA. JAK/STAT, Raf/MEK/ERK, PI3 K/Akt and BCR-ABL in cell cycle progression and leukemogenesis. Leukemia. 2004;18(2):189-218.

112. Jin A, Kurosu T, Tsuji K, Mizuchi D, Arai A, Fujita H, et al. BCR/ABL and IL-3 activate Rap1 to stimulate the B-Raf/MEK/Erk and Akt signaling pathways and to regulate proliferation, apoptosis, and adhesion. Oncogene. 2006;25(31):4332-40.

113. Mizuchi D, Kurosu T, Kida A, Jin ZH, Jin A, Arai A, et al. BCR/ABL activates Rap1 and B-Raf to stimulate the MEK/Erk signaling pathway in hematopoietic cells. Biochem Biophys Res Commun. 2005;326(3):645-51.

114. Mandanas RA, Leibowitz DS, Gharehbaghi K, Tauchi T, Burgess GS, Miyazawa K, et al. Role of p21 RAS in p210 bcr-abl transformation of murine myeloid cells. Blood. 1993;82(6):1838-47.

115. Baum KJ, Ren R. Effect of Ras inhibition in hematopoiesis and BCR/ABL leukemogenesis. J Hematol Oncol. 2008;1:5.

116. Brozik A, Casey NP, Hegedus C, Bors A, Kozma A, Andrikovics H, et al. Reduction of Bcr-Abl function leads to erythroid differentiation of K562 cells via downregulation of ERK. Ann N Y Acad Sci. 2006;1090:344-54.

117. Ozaki K, Kosugi M, Baba N, Fujio K, Sakamoto T, Kimura S, et al. Blockade of the ERK or PI3 K-Akt signaling pathway enhances the cytotoxicity of histone deacetylase inhibitors in tumor cells resistant to gefitinib or imatinib. Biochem Biophys Res Commun. 2010;391(4):1610-5.

118. Basak P, Chatterjee S, Das P, Das M, Pereira JA, Dutta RK, et al. Leukemic stromal hematopoietic microenvironment negatively regulates the normal hematopoiesis in mouse model of leukemia. Chin J Cancer. 2010;29(12):969-79.

119. Hickey FB, England K, Cotter TG. Bcr-Abl regulates osteopontin transcription via Ras, PI-3 K, aPKC, Raf-1, and MEK. J Leukoc Biol. 2005;78(1):289-300.

120. Asmussen J, Lasater EA, Tajon C, Oses-Prieto J, Jun YW, Taylor BS, et al. MEK-dependent negative feedback underlies BCR-ABL-mediated oncogene addiction. Cancer Discov. 2014;4(2):200-15.

121. Kuroda I, Inukai T, Zhang $X$, Kikuchi J, Furukawa Y, Nemoto A, et al. $B C R-A B L$ regulates death receptor expression for TNF-related apoptosisinducing ligand (TRAIL) in Philadelphia chromosome-positive leukemia. Oncogene. 2013;32(13):1670-81.

122. Zhao S, Asgary Z, Wang $Y$, Goodwin $R$, Andreeff M, Younes A. Functional expression of TRAIL by lymphoid and myeloid tumour cells. Br J Haematol. 1999;106(3):827-32.

123. De Carvalho DD, Binato R, Pereira WO, Leroy JM, Colassanti MD, Proto-Siqueira R, et al. BCR-ABL-mediated upregulation of PRAME is responsible for knocking down TRAIL in CML patients. Oncogene. 2011;30(2):223-33.

124. Uno K, Inukai T, Kayagaki N, Goi K, Sato H, Nemoto A, et al. TNFrelated apoptosis-inducing ligand (TRAIL) frequently induces apoptosis in Philadelphia chromosome-positive leukemia cells. Blood. 2003;101(9):3658-67.

125. Nimmanapalli R, Porosnicu M, Nguyen D, Worthington E, O’Bryan E, Perkins C, et al. Cotreatment with STI-571 enhances tumor necrosis factor alpha-related apoptosis-inducing ligand (TRAIL or apo-2L)-induced apoptosis of Bcr-Abl-positive human acute leukemia cells. Clin Cancer Res. 2001;7(2):350-7.

126. Park SJ, Kim MJ, Kim HB, Kang CD, Kim SH. Sensitization of imatinibresistant CML cells to TRAIL-induced apoptosis is mediated through down-regulation of Bcr-Abl as well as c-FLIP. Biochem J. 2009;420(1):73-81.

127. Raimondo S, Naselli F, Fontana S, Monteleone F, Lo Dico A, Saieva L, et al. Citrus limon-derived nanovesicles inhibit cancer cell proliferation and suppress CML xenograft growth by inducing TRAIL-mediated cell death. Oncotarget. 2015;6:1951.

128. Perrotti D, Cesi V, Trotta R, Guerzoni C, Santilli G, Campbell K, et al. BCR$\mathrm{ABL}$ suppresses $\mathrm{C} / \mathrm{EBPalpha}$ expression through inhibitory action of hnRNP E2. Nat Genet. 2002;30(1):48-58. 
129. Chen XM, Feng WL, Zhao SQ, Zeng JM, Bai WJ, Wang XZ, et al. Effect and possible mechanism of HnRNP E2 decoy RNA on proliferation of K562 leukemia cells. Ai Zheng. 2006;25(7):793-7.

130. Chang JS, Santhanam R, Trotta R, Neviani P, Eiring AM, Briercheck E, et al. High levels of the BCR/ABL oncoprotein are required for the MAPK-hnRNP-E2 dependent suppression of C/EBPalpha-driven myeloid differentiation. Blood. 2007;110(3):994-1003.

131. Zhang P, Iwasaki-Arai J, I wasaki H, Fenyus ML, Dayaram T, Owens BM, et al. Enhancement of hematopoietic stem cell repopulating capacity and self-renewal in the absence of the transcription factor C/EBP alpha. Immunity. 2004;21(6):853-63.

132. Eiring AM, Harb JG, Neviani P, Garton C, Oaks JJ, Spizzo R, et al. miR-328 functions as an RNA decoy to modulate hnRNP E2 regulation of mRNA translation in leukemic blasts. Cell. 2010;140(5):652-65.

133. Fragliasso V, Chiodo Y, Ferrari-Amorotti G, Soliera AR, Manzotti G, Cattelani S, et al. Phosphorylation of serine 21 modulates the proliferation inhibitory more than the differentiation inducing effects of C/EBPalpha in K562 cells. J Cell Biochem. 2012;113(5):1704-13.

134. Schuster C, Forster K, Dierks H, Elsasser A, Behre G, Simon N, et al. The effects of Bcr-Abl on C/EBP transcription-factor regulation and neutrophilic differentiation are reversed by the Abl kinase inhibitor imatinib mesylate. Blood. 2003;101(2):655-63.

135. Ferrari-Amorotti G, Mariani SA, Novi C, Cattelani S, Pecorari L, Corradini $F$, et al. The biological effects of C/EBPalpha in K562 cells depend on the potency of the $\mathrm{N}$-terminal regulatory region, not on specificity of the DNA binding domain. J Biol Chem. 2010;285(40):30837-50.

136. Tavor S, Park DJ, Gery S, Vuong PT, Gombart AF, Koeffler HP. Restoration of C/EBPalpha expression in a BCR-ABL + cell line induces terminal granulocytic differentiation. J Biol Chem. 2003;278(52):52651-9.

137. Ferrari-Amorotti G, Keeshan K, Zattoni M, Guerzoni C, lotti G, Cattelani S, et al. Leukemogenesis induced by wild-type and STI571-resistant BCR/ ABL is potently suppressed by C/EBPalpha. Blood. 2006;108(4):1353-62.

138. Guerzoni C, Bardini M, Mariani SA, Ferrari-Amorotti G, Neviani P, Panno $\mathrm{ML}$, et al. Inducible activation of CEBPB, a gene negatively regulated by $B C R / A B L$, inhibits proliferation and promotes differentiation of $B C R /$ ABL-expressing cells. Blood. 2006;107(10):4080-9.

139. Soliera AR, Lidonnici MR, Ferrari-Amorotti G, Prisco M, Zhang Y, Martinez RV, et al. Transcriptional repression of c-Myb and GATA-2 is involved in the biologic effects of C/EBPalpha in p210BCR/ABL-expressing cells. Blood. 2008;112(5):1942-50

140. Wagner K, Zhang P, Rosenbauer F, Drescher B, Kobayashi S, Radomska $\mathrm{HS}$, et al. Absence of the transcription factor CCAAT enhancer binding protein alpha results in loss of myeloid identity in bcr/abl-induced malignancy. Proc Natl Acad Sci USA. 2006;103(16):6338-43.

141. McClellan JS, Dove C, Gentles AJ, Ryan CE, Majeti R. Reprogramming of primary human Philadelphia chromosome-positive B cell acute lymphoblastic leukemia cells into nonleukemic macrophages. Proc Natl Acad Sci USA. 2015;112(13):4074-9.

142. Annamaneni S, Kagita S, Gorre M, Digumarti RR, Satti V, Battini MR. Methylation status of CEBPA gene promoter in chronic myeloid leukemia. Hematology. 2014;19(1):42-4.

143. Zhang SP, Niu YN, Yuan N, Zhang AH, Chao D, Xu QP, et al. Role of autophagy in acute myeloid leukemia therapy. Chin J Cancer 2013;32(3):130-5.

144. Kamitsuji Y, Kuroda J, Kimura S, Toyokuni S, Watanabe K, Ashihara E, et al. The Bcr-Abl kinase inhibitor INNO-406 induces autophagy and different modes of cell death execution in Bcr-Abl-positive leukemias. Cell Death Differ. 2008;15(11):1712-22.

145. Carew JS, Nawrocki ST, Kahue CN, Zhang H, Yang C, Chung L, et al. Targeting autophagy augments the anticancer activity of the histone deacetylase inhibitor SAHA to overcome Bcr-Abl-mediated drug resistance. Blood. 2007:110(1):313-22.

146. Calabretta B, Salomoni P. Suppression of autophagy by BCR/ABL. Front Biosci (Schol Ed). 2012:4:453-60.

147. Zeng X, Zhao H, Li Y, Fan J, Sun Y, Wang S, et al. Targeting Hedgehog signaling pathway and autophagy overcomes drug resistance of BCRABL-positive chronic myeloid leukemia. Autophagy. 2015;11(2):355-72.

148. Altman BJ, Jacobs SR, Mason EF, Michalek RD, MacIntyre AN, Coloff JL, et al. Autophagy is essential to suppress cell stress and to allow BCRAbl-mediated leukemogenesis. Oncogene. 2011;30(16):1855-67.
149. Gounaris E, Wu EJ, Vakana E, Sharma B, Bogyo M, Altman JK, et al. Autophagic degradation of the BCR-ABL oncoprotein and generation of antileukemic responses by arsenic trioxide. Blood. 2012;120(17):3555-62.

150. Turner SD, Alexander DR. Fusion tyrosine kinase mediated signalling pathways in the transformation of haematopoietic cells. Leukemia. 2006;20(4):572-82.

151. Fernandes MS, Reddy MM, Gonneville JR, DeRoo SC, Podar K, Griffin $J D$, et al. BCR-ABL promotes the frequency of mutagenic single-strand annealing DNA repair. Blood. 2009;114(9):1813-9.

152. Nowicki MO, Falinski R, Koptyra M, Slupianek A, Stoklosa T, Gloc E, et al. $B C R / A B L$ oncogenic kinase promotes unfaithful repair of the reactive oxygen species-dependent DNA double-strand breaks. Blood. 2004;104(12):3746-53.

153. Cramer K, Nieborowska-Skorska M, Koptyra M, Slupianek A, Penserga $E T$, Eaves $C J$, et al. BCR/ABL and other kinases from chronic myeloproliferative disorders stimulate single-strand annealing, an unfaithful DNA double-strand break repair. Cancer Res. 2008;68(17):6884-8.

154. Slupianek A, Poplawski T, Jozwiakowski SK, Cramer K, Pytel D, Stoczynska E, et al. BCR/ABL stimulates WRN to promote survival and genomic instability. Cancer Res. 2011;71(3):842-51.

155. Laneuville P, Sun G, Timm M, Vekemans M. Clonal evolution in a myeloid cell line transformed to interleukin-3 independent growth by retroviral transduction and expression of p210bcr/abl. Blood. 1992;80(7):1788-97.

156. Gerber JM, Gucwa JL, Esopi D, Gurel M, Haffner MC, Vala M, et al. Genome-wide comparison of the transcriptomes of highly enriched normal and chronic myeloid leukemia stem and progenitor cell populations. Oncotarget. 2013;4(5):715-28.

157. Ilaria RL, Jr. Pathobiology of lymphoid and myeloid blast crisis and management issues. Hematology Am Soc Hematol Educ Program. 2005:188-94.

158. Perrotti D, Jamieson C, Goldman J, Skorski T. Chronic myeloid leukemia: mechanisms of blastic transformation. J Clin Invest. 2010;120(7):2254-64.

159. Skorski T. Genetic mechanisms of chronic myeloid leukemia blastic transformation. Curr Hematol Malig Rep. 2012;7(2):87-93.

160. Cazzaniga G, van Delft FW, Lo Nigro L, Ford AM, Score J, lacobucci I, et al. Developmental origins and impact of BCR-ABL1 fusion and IKZF1 deletions in monozygotic twins with $\mathrm{Ph}+$ acute lymphoblastic leukemia. Blood. 2011;118(20):5559-64.

161. Theocharides AP, Dobson SM, Laurenti E, Notta F, Voisin V, Cheng PY, et al. Dominant-negative Ikaros cooperates with BCR-ABL1 to induce human acute myeloid leukemia in xenografts. Leukemia. 2015;29(1):177-87.

162. Beer PA, Knapp DJ, Miller PH, Kannan N, Sloma I, Heel K, et al. Disruption of IKAROS activity in primitive chronic-phase CML cells mimics myeloid disease progression. Blood. 2015;125(3):504-15.

163. Mullighan CG, Miller CB, Radtke I, Phillips LA, Dalton J, Ma J, et al. BCR-ABL1 lymphoblastic leukaemia is characterized by the deletion of Ikaros. Nature. 2008:453(7191):110.

164. Mullighan CG, Su X, Zhang J, Radtke I, Phillips LA, Miller CB, et al. Deletion of IKZF1 and prognosis in acute lymphoblastic leukemia. N Engl J Med. 2009;360(5):470-80.

165. Dupuis A, Gaub MP, Legrain M, Drenou B, Mauvieux L, Lutz P, et al. Biclonal and biallelic deletions occur in 20\% of B-ALL cases with IKZF1 mutations. Leukemia. 2013;27(2):503-7.

166. de Rooij JD, Beuling E, van den Heuvel-Eibrink MM, Obulkasim A, Baruchel A, Trka J, et al. Recurrent deletions of IKZF1 in pediatric acute myeloid leukemia. Haematologica. 2015;100:1151.

167. lacobucci I, Storlazzi CT, Cilloni D, Lonetti A, Ottaviani E, Soverini S, et al. Identification and molecular characterization of recurrent genomic deletions on 7p12 in the IKZF1 gene in a large cohort of BCR-ABL1positive acute lymphoblastic leukemia patients: on behalf of Gruppo Italiano Malattie Ematologiche dell'Adulto Acute Leukemia Working Party (GIMEMA AL WP). Blood. 2009;114(10):2159-67.

168. Lin $\mathrm{H}$, Grosschedl R. Failure of B-cell differentiation in mice lacking the transcription factor EBF. Nature. 1995;376(6537):263-7.

169. Ramirez J, Lukin K, Hagman J. From hematopoietic progenitors to B cells: mechanisms of lineage restriction and commitment. Curr Opin Immunol. 2010;22(2):177-84. 
170. Cobaleda C, Schebesta A, Delogu A, Busslinger M. Pax5: the guardian of B cell identity and function. Nat Immunol. 2007;8(5):463-70.

171. Familiades J, Bousquet M, Lafage-Pochitaloff M, Bene MC, Beldjord $\mathrm{K}$, De Vos J, et al. PAX5 mutations occur frequently in adult B-cell progenitor acute lymphoblastic leukemia and PAX5 haploinsufficiency is associated with BCR-ABL1 and TCF3-PBX1 fusion genes: a GRAALL study. Leukemia. 2009;23(11):1989-98.

172. lacobucci I, Lonetti A, Paoloni F, Papayannidis C, Ferrari A, Storlazzi CT, et al. The PAX5 gene is frequently rearranged in BCR-ABL1-positive acute lymphoblastic leukemia but is not associated with outcome. A report on behalf of the GIMEMA acute leukemia working party. Haematologica. 2010;95(10):1683-90.

173. Goga A, McLaughlin J, Afar DE, Saffran DC, Witte ON. Alternative signals to RAS for hematopoietic transformation by the BCR-ABL oncogene. Cell. 1995;82(6):981-8.

174. Rouault JP, Samarut C, Duret L, Tessa C, Samarut J, Magaud JP. Sequence analysis reveals that the BTG1 anti-proliferative gene is conserved throughout evolution in its coding and 3 ' non-coding regions. Gene. 1993;129(2):303-6.

175. Iwai K, Hirata K, Ishida T, Takeuchi S, Hirase T, Rikitake Y, et al. An anti-proliferative gene BTG1 regulates angiogenesis in vitro. Biochem Biophys Res Commun. 2004:316(3):628-35.

176. Xie J, Wang $Q$, Wang $Q$, Yao H, Wen L, Ma L, et al. High frequency of BTG1 deletions in patients with BCR-ABL1-positive acute leukemia. Cancer Genet. 2014;207(5):226-30.

177. Waanders E, Scheijen B, van der Meer LT, van Reijmersdal SV, van Emst L, Kroeze $Y$, et al. The origin and nature of tightly clustered BTG1 deletions in precursor B-cell acute lymphoblastic leukemia support a model of multiclonal evolution. PLoS Genet. 2012;8(2):e1002533.

178. van Galen JC, Kuiper RP, van Emst L, Levers M, Tijchon E, Scheijen B, et al. BTG1 regulates glucocorticoid receptor autoinduction in acute lymphoblastic leukemia. Blood. 2010;115(23):4810-9.

179. Zheng HC, Li J, Shen DF, Yang XF, Zhao S, Wu YZ, et al. BTG1 expression correlates with pathogenesis, aggressive behaviors and prognosis of gastric cancer: a potential target for gene therapy. Oncotarget. 2015;6:19685

180. Nacheva EP, Brazma D, Virgili A, Howard-Reeves J, Chanalaris A, Gancheva K, et al. Deletions of immunoglobulin heavy chain and T cell receptor gene regions are uniquely associated with lymphoid blast transformation of chronic myeloid leukemia. BMC Genom. 2010;11:41.

181. Chomel JC, Bonnet ML, Sorel N, Bertrand A, Meunier MC, Fichelson $\mathrm{S}$, et al. Leukemic stem cell persistence in chronic myeloid leukemia patients with sustained undetectable molecular residual disease. Blood. 2011;118(13):3657-60

182. Chu S, McDonald T, Lin A, Chakraborty S, Huang Q, Snyder DS, et al. Persistence of leukemia stem cells in chronic myelogenous leukemia patients in prolonged remission with imatinib treatment. Blood. 2011;118(20):5565-72.

183. Graham SM, Jorgensen HG, Allan E, Pearson C, Alcorn MJ, Richmond L, et al. Primitive, quiescent, Philadelphia-positive stem cells from patients with chronic myeloid leukemia are insensitive to STI571 in vitro. Blood. 2002;99(1):319-25.
184. Chomel JC, Sorel N, Guilhot J, Guilhot F, Turhan AG. BCR-ABL expression in leukemic progenitors and primitive stem cells of patients with chronic myeloid leukemia. Blood. 2012;119(12):2964-5.

185. Chu S, Xu H, Shah NP, Snyder DS, Forman SJ, Sawyers CL, et al. Detection of BCR-ABL kinase mutations in CD34 + cells from chronic myelogenous leukemia patients in complete cytogenetic remission on imatinib mesylate treatment. Blood. 2005;105(5):2093-8.

186. Sorel N, Bonnet ML, Guillier M, Guilhot F, Brizard A, Turhan AG. Evidence

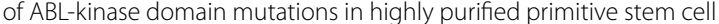
populations of patients with chronic myelogenous leukemia. Biochem Biophys Res Commun. 2004;323(3):728-30.

187. Soverini S, Colarossi S, Gnani A, Rosti G, Castagnetti F, Poerio A, et al. Contribution of $\mathrm{ABL}$ kinase domain mutations to imatinib resistance in different subsets of Philadelphia-positive patients: by the GIMEMA Working Party on Chronic Myeloid Leukemia. Clin Cancer Res. 2006;12(24):7374-9.

188. O'Hare T, Eide CA, Deininger MW. Bcr-Abl kinase domain mutations, drug resistance, and the road to a cure for chronic myeloid leukemia. Blood. 2007:110(7):2242-9.

189. Peng C, Li D, Li S. Heat shock protein 90: a potential therapeutic target in leukemic progenitor and stem cells harboring mutant BCR-ABL resistant to kinase inhibitors. Cell Cycle. 2007;6(18):2227-31.

190. Khajapeer KV, Baskaran R. Hsp90 inhibitors for the treatment of chronic myeloid leukemia. Leuk Res Treat. 2015;2015:757694.

191. Liu X, Kung A, Malinoski B, Prakash GK, Zhang C. Development of alkyne-containing pyrazolopyrimidines to overcome drug resistance of Bcr-Abl kinase. J Med Chem. 2015;58(23):9228-37.

192. Jabbour E, Kantarjian H. Chronic myeloid leukemia: 2016 update on diagnosis, therapy, and monitoring. Am J Hematol. 2016;91 (2):252-65.

193. Biernaux C, Loos M, Sels A, Huez G, Stryckmans P. Detection of major bcr-abl gene expression at a very low level in blood cells of some healthy individuals. Blood. 1995;86(8):3118-22.

194. Butt NM, Wang L, Abu-Eisha HM, Christmas SE, Clark RE. BCR-ABL-specific $T$ cells can be detected in healthy donors and in chronic myeloid leukemia patients following allogeneic stem cell transplantation. Blood. 2004;103(8):3245

195. Hanahan D, Weinberg RA. Hallmarks of cancer: the next generation. Cell. 2011;144(5):646-74.

196. Landau DA, Carter SL, Getz G, Wu CJ. Clonal evolution in hematological malignancies and therapeutic implications. Leukemia. 2014;28(1):34-43.

197. Hainaut P, Plymoth A. Targeting the hallmarks of cancer: towards a rational approach to next-generation cancer therapy. Curr Opin Oncol. 2013;25(1):50-1.

198. Mullighan CG, Goorha S, Radtke I, Miller CB, Coustan-Smith E, Dalton JD, et al. Genome-wide analysis of genetic alterations in acute lymphoblastic leukaemia. Nature. 2007;446(7137):758-64.

\section{Submit your next manuscript to BioMed Central and we will help you at every step:}

- We accept pre-submission inquiries

- Our selector tool helps you to find the most relevant journal

- We provide round the clock customer support

- Convenient online submission

- Thorough peer review

- Inclusion in PubMed and all major indexing services

- Maximum visibility for your research

Submit your manuscript at www.biomedcentral.com/submit 